\title{
7
}

\section{"The Ancient Consciousness of Woman": A Feminist Archaeology of Daniel Deronda and Between the Acts}

As the last acts of their careers as novelists, Eliot and Woolf both present perhaps the darkest, most equivocal and open-ended of their works. Daniel Deronda and Between the Acts raise the ominous question of what comes next for a civilization rotting from within, yet both works find sources of energy in that decay. And now? "I shall live," cries Gwendolen, who once meant not only to live but to lead, whereas the dying Hebrew prophet assures Daniel, the future leader, "Is it not begun? . . . We shall live together" (DD 879, 882). "Then the curtain rose. They spoke," writes Miss La Trobe of her archetypal man and woman, who fight to the death like animals; the fruit of their differences may be a child or a play that shall live (BA 219). The doubtful promise of these endings emerges from a covert but violent warfare that has shaken the foundations of the patriarchal family and religion.

The heart of the darkness in these novels is gender conflict, which I will approach on two fronts, on the one hand the networks of sacred allusions and themes, and on the other, characterization and action. Like the "separate spheres" I have frequently considered, these fronts are inseparable, of course. To me the most remarkable aspect of both novels-and what gives these different works most in common-is the daring conjunction of religious and cultural history with the private theatricals of the novel of manners. In both final novels, the stress between patriarchal culture and women of vocation has become impossible to ease. It is no longer a question of extending to the rare, aristocratic woman a special license to trespass, as in Romola and Orlando; it is no longer possible to pursue a social history of metonymic detail and interdependent spheres, as in Felix Holt and The Years. Here the fiction that calls women nature, men culture, women the personal 
or particular, men the public or universal, has become an excruciating delusion. Who would buy the patriarchal lie that founds modern European civilization? Who could bear the truths that would destroy it?

Feminist tactics for unearthing such truths have often taken the two approaches I follow here, which for simplicity I term vocational and archaeological. The vocational feminist analysis has been the basis for most feminist literary criticism (and it has set the pattern for much of my own study); it may focus on the vocation of female characters in line with biographical readings of women of letters, and it may consider genre and plot, social convention, or the historical conditioning of authorship and readership, among other rewarding concerns. Yet the vocational front can become narrow without an engagement on the archaeological front as well. Thus many feminist theorists and critics have insisted that the struggle of heroines and women writers to break silence must be placed in deeper and more far-reaching contexts: beyond the modern European middle class; beyond phallogocentrism; or Beyond God the Father with Mary Daly or Merlin Stone. From this perspective, there is no articulate voice proper to woman in Western civilization, whatever the women of letters and their female characters may strive for or achieve. Only the triumphant laughter of Demeter, of Medusa, of the hysteric or priestess of jouissance (Cixous and Clément 33-39) promises a different story.

In this discussion of the last novels I set out by a less explored archaeological route, which often intersects with the vocational path. The authors delve into cultural memory in order to reveal primitive tensions behind the more immediate question of what women are to do. As we have seen, the novels of Eliot and Woolf generally answer that immediate question negatively: women cannot hope for perfection both of the art and of the life, cannot, as heroines or as living women, figure in both ambitious and erotic plots without paying a great price of suffering. ${ }^{1}$ What happens when the novels defy this "thou-shalt-not" without relying, as in Romola and Orlando, on the excuses of historical remoteness or aristocratic privilege? Instead of an array of happily adjusted, successful women, we find eruptions of frustration and rage exceeding Mrs. Transome's, and we find strange labyrinths of primitive imagery and hints of alien rites exceeding those in The Years.

\footnotetext{
${ }^{1}$ Aurora Leigh postpones the erotic plot till she has become an eminent poet, at which time she concedes: "No perfect artist is developed here / From any imperfect woman. . . . / Art is much, but love is more" (Book 9, 341). None of Eliot's or Woolf's characters manages to "have it all" in this way.
} 
Surely there is a familiar logic to the rage-you beat me, I fight back-and feminist critics have been quick to locate such textual revenge of the oppressed (Eliot's Alcharisi is a star in feminist criticism; see Pell; Gallagher, "The Prostitute," 54-55; Rosenman, "Women's Speech"). But are we as familiar with the archaic forms of the return of the repressed in these novels? To me it is a haunting question why Eliot and Woolf should frame their vocational feminism in such bizarre archaeological fragments, and the fragments themselves have a startling freshness and antiquity when brought to light. Lily Briscoe "imagined how in the chambers of the mind and heart of the woman ... . were stood, like the treasures in the tombs of kings, tablets bearing sacred inscriptions" that would always remain secret. But Lily the archaeologist has a desire not so much to decipher the code as to enter those chambers and stay there: "It was not knowledge but unity that she desired . . . nothing that could be written in any language known to men, but intimacy itself, which is knowledge" (TL 79). In my readings of these novels, I will try to return alive out of the underworld, bearing signs of what Eliot calls "the treasure of human affections" (DD 160) - an intimate knowledge of primitive beliefs, of a feminine unconscious-without seeking unity with the deadly myths of sacred womanhood.

A novel completed during World War II inevitably takes a different view of cultural origins, the design of history, and narrative generally than one published in the 1870 . Between the Acts seems to revel in the irresolution that Daniel Deronda laments, drawing recreative energies out of the primitive mud that threatens to swallow civilization in both novels. ${ }^{2}$ Yet both novels strive to shore up tradition, whether a restored Judaism or English literary history; the first turns to inherited law and religion, the second to a collective, spontaneously restored spirit: "We're the oracles . . . a foretaste of our own religion" (BA 198). Woolf's modern question, prompted by the nightmares of nationalism and anti-Semitism that Eliot's novel warned of, could well be asked in both works: "How's . . the great wall, which we call, perhaps miscall, civilization, to be built by . . . orts, scraps and fragments like ourselves?" (BA 188). In the figures of Mordecai and Daniel, however, Eliot seems to reconstitute the humanist individual under the authority of a teleo-

\footnotetext{
${ }^{2}$ Although it is unlikely that Woolf had Daniel Deronda in view as a specific precedent among Eliot's novels-she scarcely referred to this novel except as evidence of Eliot's final decline ("GE" [1921]) - in effect Between the Acts extends and develops the speculation in Daniel Deronda on the resurgence of the primitive common life alongside contemporary redefinitions of women's vocation.
} 
logical monotheism, rising above all modern dissolution. Why should these women writers have strained so hard to preserve a tradition that they largely condemned? Before entering the labyrinths of the pagan and Judeo-Christian, the primitive and civilized in these novels, I take a "vocational" detour to consider the novelists' responses to their historical moment and cultural mission. At the end of this chapter I return to the vocational preoccupations of these novels, with their proliferation of women artists, including the most powerful and enraged artist figures in Eliot's or Woolf's oeuvres, the Alcharisi and Miss La Trobe.

\section{The Last Novels in Context: Authors and Audience, History and Form}

Both final novels appear to have been formed under pressure of political upheaval, of the loss of an assured public, and of a craving for generic innovation. In both works the authors have constructed time scales at once more expansive and more immediate than usual. Daniel Deronda, unlike Eliot's earlier novels, occurs within a decade or so before the date of publication in 1876; it registers the international impact of such events as the American Civil War and the FrancoPrussian War, while it prepares for the restoration of a Jewish homeland that had been prophesied in ancient scripture. The title itself subscribes to the Judaic cyclical model of history; the hero's name invokes both the princely exile reared as advisor in the gentile king's house and a rounding out of the history of the Jews (The Book of Daniel 4:8-9). Between the Acts suggests a more doubtful relation between prophetic pretexts and fulfillment. ${ }^{3}$ Set in 1939, during the "present" of composition (1938-41), it is an idyll of a few hours bounded by war (like the first and last parts of To the Lighthouse), while it follows the same span of English literary history as Orlando. Like several of Woolf's novels and like only Daniel Deronda among Eliot's, Between the Acts ends "here and now," facing a terrifying future; its first readers were in the midst of the cataclysm anticipated in the novel. Rather than

\footnotetext{
${ }^{3}$ Eliot's use of Judeo-Christian heritage would seem to affirm a teleological model of history, but her narrator at the outset announces, "No retrospect will take us to the true beginning" - or project a certain end (35). Woolf rather adverts to a myth of eternal return, suggesting the pagan or Viconian model of historical cycles; repetition is the most striking aspect of the book (Hartman 74, 80-81). J. Hillis Miller notes in Between the Acts the combination of repetitive "musical, architectural form" with realistic "social notations" like "those of Austen or Eliot" and a chronological plotline of history (Fiction 206-9).
} 
closing a circle, it divides what it also connects: the two World Wars; the sexual acts of Isa and Giles; the acts of the pageant and of the disjointed novel-play that encloses it; and the beginning and end of human history. ${ }^{4}$

The stress laid on the form of history in each of these novels underscores similar arguments about the impossibility of continuing on the present course, particularly because of the abuses of patriarchal and nationalistic power. This is not to say that these works blame all contemporary suffering on the bourgeois family or the British nation or even national spirit itself. The intolerance of the tribe for difference within and without is to blame, not the social bonds themselves, which perhaps prevent the worse tortures of a state of nature. British imperialism and European fascism are harshly satirized, but both novels mount last-ditch defenses of a more worthy nationalismthe shared historic achievement of the chosen people or the chosen literature. Eliot's Theophrastus Such calls for a nationalism without xenophobia; the English must recognize the right of all peoples (including the Jews) to a homeland if they themselves are to "resist conquest with the very breasts of their women" ("The Modern Hep! Hep! Hep!" TS 189-90). Between the Acts confronts not only the threat of foreign domination, but also the incompatible desires to defend the homeland and to liberate the women while opening the borders to the alien or suppressed. "And what about the Jews?" exclaims a nameless member of the audience. "People like ourselves, beginning life again" (121). National survival depends on tolerating the full diversity of "people like ourselves," both novels say. In the later novel, Klesmer's and Deronda's tolerant cosmopolitanism has become the ineffectual sympathy of Lucy Swithin, who disbelieves in history and its subdivisions of ages and nations (174-75), or the comparative detachment of Cobbet of Cobb's Corner, who sees sexual vitality as the same in East and West (110).

It is difficult to sustain pluralism without relativism or indifference, without abandoning worthy tradition or yielding to the status quo, and many forces lurk ready to destroy the balance. The fragile values and the disruptive impulses together contribute to a metamorphosis of genres in these novels, as the old forms break down with the old order. Both final novels challenge the ranks, rules, and realism of the novel of manners and of English society with the more communal or fantastical powers of drama, music, or poetry. Both Daniel Deronda

\footnotetext{
"Daniel's true surname is "Charisi," an appellation for exile and for "promised redemption" (Fleishman, "Charisi," 102-4). Since each self is an acted part, an "act," Woolf's title also says "only connect." See Naremore 228-39; Fussell 267-68.
} 
and Between the Acts aspire to the condition of theater, especially in its more ancient forms. Almost all the female characters in these novels are actresses, amateur or professional, and plays-within-the-play are repeatedly staged, from Gwendolen's theatricals to the female Prospero's pageant in Between the Acts. Expanding the idea of theater held by drawing-room or village audiences, however, the authors introduce a forgotten mode of the drama often "undramatic" in the modern sense. Such drama more closely resembles the ancient communal rites of sacrifice and rebirth, and it plays down individual action in favor of collective manifestations. ${ }^{5}$ In contrast with the solitary endeavors of the painter, novelist, or poet, both drama and music can unite performers and audience in shared social ritual, inviting a return to "unpersonified feelings" in an affirmation of the "common weal."

Woolf appears to have been drawn to the theory, expressed by her friend Jane Harrison in Ancient Art and Ritual, that drama originated in rituals in which everyone participated; later, the rite ("dromenon, 'a thing done' ") was distanced from practical consequences, as actors were distinguished from spectators $(124-27,35){ }^{7}$ Like drama, music might long predate interest in individual expression, deriving from original instincts and the creations of "Anon," the unknown minstrel Woolf imagined for a projected book on English literary history begun in 1940 (Silver, " 'Anon,' " 382). Both novels are drawn to an ideal of

${ }^{5}$ A. V. Dicey complained of the substitution of "a chorus of moralists" for dramatic action in Daniel Deronda (Carroll, Critical Heritage, 399); indeed, the narrator resembles the chorus of Greek drama, while there are repeated monologues or soliloquies. Similarly, Malcolm Cowley noted that Between the Acts had "no plot . . . no sense of drama or dialectic." Instead, Woolf substituted the chorus, the collective "we" for the "I," the ritual act for the plot (Majumdar and McLaurin 448; VW Diary 5: 135).

${ }^{6}$ The terms are Jane Harrison's $(233,246)$. Marcus compares Between the Acts to The Years, with its similar Greek chorus, reference to a benefit pageant, and operatic subtext. In a review of 1909, Woolf wrote on a performance of Wagner in Bayreuth where the audience came out to view the landscape between the acts (Marcus, "Sources," 1-2; Languages, 16-17, 36-39).

7See Maika 7-9. Harrison shares much of Nietzsche's vision of the origins of tragedy and of the artistic creator who becomes "at once poet, actor, and spectator" (Maika 68; Nietzsche, Tragedy, 36-42, 52). Eliot's views have some Carlylean elements in common with Nietzsche, in spite of his distaste for Eliot's moralism (Myers, Teaching, 119-24; Beer, Past, 76-77). Brockett entertains theories that theater originated in storytelling or in dance alongside the still-viable theory that it originated in ritual (6-7). Harrison seems to incite Woolf to write Between the Acts in her account of ancient origins of theater: "The whole body of worshippers would gather, just as now-a-days the whole community will assemble on a village green. . . . All are actors. . . . It is in the common act, . . or collective emotion, that ritual starts" (126). Hoff attacks Cuddy-Keane for ignoring the role Harrison assigns to the leader of the dithyramb or spring festival, but I agree with Cuddy-Keane ("Reply") that Harrison distinguishes this form of transferable and impersonal leadership from the individualistic artist-as-originator, without imagining a purely nonhierarchical community. 
nonindividualistic art. The composer Klesmer, though a Romantic believer in individual genius, nevertheless perceives the artist's vocation as one of self-sacrifice and willingness to die anonymous and poor. For Eliot, music helps us "to escape the limitations" of self, and the true genius lives more "for the next age . . . than for his own" (Baker, Introduction, 31-35; Harrison 233-34; Eliot, "Liszt, Wagner, and Weimar," 98); liturgical music can lend a "sense of communion" with "long generations of struggling fellow-men" (DD 416). Miss La Trobe never poses as a genius, but sweats with her actors behind the scenes. She enlists the help, for her pageant, of "Bach, Handel, Beethoven, Mozart or nobody famous" (BA 188), as well as the incidental music of cows, rain, or airplanes, precisely for the sake of such liturgical communion. Instead of the single, signed, and formally staged play, drama like music becomes the history of a people in microcosm. ${ }^{8}$

The generic experimentation in these last works served the critique of modern deracinated civilization, but it also helped the women of letters in their continuing effort to escape the woman's sphere of the novel. Eliot had turned repeatedly to poetry (with drama, still the privileged literary form), and she had successfully published several long poems, including one, The Spanish Gypsy, that had originated as a play (Eliot abandoned it to work on the "tragedy" of Mrs. Transome). ${ }^{9}$ Yet her desire to write a play remained unsatisfied. In June 1873 she told Lewes her plan for "novel and play Deronda" (Haight 471). For Woolf as well, a leaning toward poetry joined with an interest in the most public literary form, the drama. Since the 1920s, Woolf had been resisting the designation "novel" for what she wrote, and had incorporated the lyric, the elegy, and the essay in her fictional forms. Her one play, Freshwater, privately performed in 1935, anticipated her last novel by recreating the cultivated circle of her greataunt Julia Cameron at a country retreat (Bell 2: 189). ${ }^{10}$ She conceived Between the Acts as a "Play" or a "medley," to include "poems (in metre)" to channel her "prose lyric vein, which . . I overdo" (VW

\footnotetext{
${ }^{8}$ Daniel reads a passage from Leopold Zunz on the "National Tragedy" of the Jews "lasting for fifteen hundred years, in which the poets and the actors were also the heroes" (575).

${ }^{9}$ The notebooks containing Eliot's research on Jewish subjects also show her continuing study of poetry and prosody (Baker, Introduction, 11-13). In the 186os and 1870s, Eliot wrote the poetry that was collected in The Legend of Jubal and Other Poems (1874) (Haight 406).

${ }^{10}$ The impulse to preserve a "fortress of civilization" and the memory of such figures as Tennyson (played by Julian Bell, killed in the Spanish Civil War) carried over from this play to Between the Acts.
} 
Diary 5: 139, 193, 200). Isa's private verse and Eliot's epigraphs in Daniel Deronda in different ways give vent to the lyric, with its evident temptations to personality, whereas the novels take the larger, impersonal scope of public drama.

In both works, the once quiet territory of the English novel of manners has been conquered not only by a generic medley but also by international strife. ${ }^{11}$ Austen's stock in trade-the three or four families in a country village, the flirtatious theatricals, the misplaced affections and trusts, and the comic resolution in marriage-was transformed when Eliot added scenes of Jewish life, and then again when Woolf interpolated the drama of English literature itself. Both amplifications of domestic fiction prove the interpenetration of provincial family life and international politics. Daniel's search for family fulfills his promise as political leader, while through him the history of the Jews intersects with Gwendolen's marriage plot. Miss La Trobe, outside the family, creates a pageant that challenges social and artistic class systems; ${ }^{12}$ ordinary people play historical leaders, and everyone unknowingly participates in a kind of allegory linking the family romance and world politics. In neither Daniel Deronda nor Between the Acts, however, are genteel hierarchies altogether discarded. Daniel will continue to behave like a proper English gentleman in the East, and vulgar Jews and unruly women will be left behind (Edgar Rosenberg notes that Eliot still relies on stereotypes of the Jews [161-84]). The canonical texture of Woolf's pageant is still best deciphered by the cultivated few, and after a day of carnival the elite family circle closes once more. Indeed, both works borrow the closure of comedy, though readers can hardly be happy about the union of the couples given all those loose ends-Gwendolen, Miss La Trobe, the horror. Is the price of peace a restoration of sexual and social hierarchy, and is such restoration even possible (Little 4-7, 92-98)?

The authors satirize contemporary society yet cling to certain vestiges of order, and they do so more urgently than ever, reflecting a change in their relations to the public. They seem to have increasingly figured themselves as outsiders within a shrinking coterie; there was no happy democracy of readers. Eliot "expected" her choice of subject to arouse "resistance and even repulsion" in the general public, but her aim was to awaken "the imagination of men and women to a vision of human claims in those races of their fellow-men who most

\footnotetext{
${ }^{11}$ On the political contexts of these novels, see, for example, Hester 115-18; Sudrann 436-39; Zwerdling 302-23; Sears 212-35.

${ }^{12}$ Pageants were frequently used for suffragette as well as Marxist propaganda (Marcus, "Sources," 2).
} 
differ from them in customs and beliefs." She waged war on "the stupidity . . . of our culture," which promoted imperialistic "dictatorialness" and a "deadness to the history which has prepared half our world for us" (GE Letters 6: 301-2). Although she aimed to instill a sense of common humanity in her public, she also displayed the antagonism of a prophet among the Philistines.

Woolf extended Eliot's challenge to the English public, yet at the same time longed for the understood right to chastise that public. She too saw a self-loving complacency, vulgarity, and xenophobia that would lunge into self-destructive war. ${ }^{13}$ Like Eliot, she anticipated that her novel "wont please anyone, if anyone should ever read it" (VW Diary 5: 160). Her sense of being an outsider increased: "The warour waiting while the knives sharpen for the operation-has taken away the outer wall of security. No echo comes back. . . I have so little sense of a public" (VW Diary 5: 299). This was an ominous lack: when the reader's "attention is distracted, in times of public crisis," she wrote, "the writer exclaims: I can write no more" (Silver, "'Anon,' " 428). Eliot's dismay over her inability to correct contemporary dissolution and prejudice cannot have been as acute as Woolf's fear of the planes over Sussex, but similar vocational doubts influenced both works.

These open-ended novels have an insistent finality: Eliot completed no other novel, and Woolf committed suicide before Between the Acts was published. After the monumental success of Middlemarch, Eliot had feared a falling off, while she felt the need to preserve her "reputation" as a kind of "eminent clergyman[ ]" (Redinger 472; GE Letters 6: 75-76). Perhaps more urgently, she felt that only a more stringent form of writing could touch the "egoism" and "moral stupidity" of a decadent empire (GE Letters 6: 99). As though like Felix Holt she had found herself unable to steer the mob, she retreated in her next work to the essay form. ${ }^{14}$ In "How We Encourage Research" it is tempting to read a bitter satire directed at her own public as a latter-day horde offering human sacrifices. Scholars become water monsters hurling "fountains of acrid mud . . . over the fresh wounds" of the noncon-

\footnotetext{
${ }^{13}$ Note the village verdict on the idiot and on savages (BA 194-99), and Bart Oliver's memories of India (17-18). Woolf writes of being "bored \& appalled by the readymade commonplaces" of village Women's Institute plays: "the minds so cheap, . . . like a bad novel" (VW Diary 5: 288).

${ }^{14}$ Stange, in "The Voices of the Essayist," observes Eliot's return to the voice of "an experienced masculine commentator" in "the declining genre of the moral essay" (317, $322,329-30)$. See "Poetry and Prose from the Notebook of an Eccentric" (1846-47) in Pinney 13-26; Haight 61; Collins 385-405.
} 
forming author, Merman (TS $40-46) .{ }^{15}$ This violent imagery anticipates the subtler satire in Between the Acts, which likewise stages presentday pagan rites and likens humans to animals in a malign inversion of evolution.

The reception of Daniel Deronda would not in itself justify the disillusionment Eliot expressed: "the painful impression that we write for a public which has no discernment of good and evil." Among some Jewish readers, at least, the response was all that she could wish (GE Letters 6: 379), and some English reviewers found much to praise (Carroll, Critical Heritage, 365-447; Perkin 67-74); good American and English sales seemed "an unmistakable guarantee that the public has been touched" (GE Letters 6: 314). But Eliot no more than Woolf could rest assured of such an anonymous "guarantee." Although before her death she did begin a novel on the Napoleonic era, it is likely that George Eliot the novelist would have had great difficulty appearing before the public after Lewes's death in 1878 , given his role in fostering her persona. ${ }^{16}$

Woolf in her last years seems to have adopted a Theophrastus-like stance toward the conventionalized oppression that binds any society, but particularly her own English educated class. At the same time, she evolved the inspiriting idea of the anonymous traditional voice. Perhaps the return of the collective madness of war and of her own madness confirmed her worst fears that history consisted of relentless repetition that no outsiders could disrupt, in spite of her hopes in Three Guineas. Her sense of vulnerability when facing publication of a novel must have seemed unendurable when the work might face no "public" at all. Just as Woolf viewed Eliot's last novel as a falling off, many reviewers accounted for Woolf's posthumously published novel as a work of declining power or as an unfinished piece, though some praised it highly (Majumdar and McLaurin 436-52). With deep misgivings and to a mixed reception, then, the women of letters strove in these unresolved works to defuse the friction between diverse cultures

\footnotetext{
${ }^{15}$ The more usual "mermaid" comes to mind, linking this essay to the images, discussed below, of Gwendolen and the Alcharisi as Lamia-like or serpentine. Eliot defends the "genius" Liszt (a model for Klesmer) concerning his apparent licentiousness: "Even an ordinary man has to pass through so many 'mud baths' before he reaches his fortieth year. . . . But, take him all in all, he is . . one of those men whom the ancients would have imagined the son of a god or goddess" ("Liszt, Wagner, and Weimar" 98). In Eliot's imagination, vocational struggles figure as mythological dramas expressing primitive drives.

${ }^{16}$ Baker, "New Eliot Manuscript." Redinger represents Eliot's marriage with Cross, and the resulting reconciliation with her brother Isaac, as reducing "her motivation to write" (483).
} 
and spirits that threatened to explode like the components of some inconceivable bomb. These bleak visions avoid becoming suicide notes for humanity, I believe, because of the ancient powers brought to light through the archaeological labors I have spoken of. The revelations were not so much reassuring as tentatively promising of women's power to redesign history.

\section{Ancient Consciousness and the Designs of History}

Now I set the stage for the role of the unconscious and the feminine in history as these novels similarly present it, before plotting, in the two following sections, the different reenactments of ancient narratives in each novel. Eliot offers a justification for Daniel Deronda's double scale-holding a woman's life and a civilization in the same balance-that applies almost equally to the cubistic Between the Acts. "Could there be a slenderer, more insignificant thread in human history," runs the famous passage,

than this consciousness of a girl . . ?-in a time, too, when ideas were with fresh vigour making armies of themselves, and the universal kinship was declaring itself fiercely: when women on the other side of the world would not mourn for the husbands and sons who died bravely in a common cause, and men stinted of bread on our side of the world heard of that willing loss and were patient: a time when the soul of man was waking to pulses which had for centuries been beating in him unheard, until their full sum made a new life of terror or of joy.

What in the midst of that mighty drama are girls and their blind visions? They are the Yea and Nay of that good for which men are enduring and fighting. In these delicate vessels is borne onward through the ages the treasure of human affections. (159-60)

This might be a pageant celebrating the sexual division of labor, the different fates of Hector and Hecuba, Tom and Maggie Tulliver, or Bart and Lucy Oliver. But a universal kinship might spell universal terror, as was repeatedly affirmed from the 1870 s to the 1930 in such concepts as the herd instinct; the treasure of human affections, as 
Eliot's novel already demonstrates, may be a Pandora's box. ${ }^{17}$ Gwendolen is indeed blind to the mighty drama beyond her immediate desires, and her store of affections is nearly empty. If history is guided by the disregarded "pulses" or "affections" of a collective unconscious, then Gwendolen's condition does have historical significance (this is no trivial marriage plot). But is she a benign influence, as the pageantry would suggest: is she some crusader's muse, or is she a Helen or a Medea? ${ }^{18}$ It is no secret in Eliot's text that a young girl might have the drives of a conqueror (when women refuse to mourn their men for whatever cause, I see a flaw in the image of the passive vessels of affection).

Gwendolen, creature of the marriage market, is fighting the world's battles in her own spirit, and the conflict reveals a gothic version of the unconscious. The epigraph of the novel is thus more revealing of the bitter effects of sexual oppression and emotional repression than the above pageantry of influence:

Let thy chief terror be of thine own soul:

There, 'mid the throng of hurrying desires

That trample o'er the dead to seize their spoil,

Lurks vengeance.

Here we encounter the modern anxiety that each "soul" harbors a mob in miniature, like the "thousands of emotions . . . in astonishing disorder" within the Woolfian representative mind ("Bennett and Brown," CE 1: 336). The self becomes a nightmare state of nature in which the repressed turn oppressors. This epigraph invites us to focus on Gwendolen, with her phobias, her accursed spoil of diamonds, and her magical vengeance on Grandcourt. She "would not mourn" her husband, who stands for the universal tyrant. But the crimes and retributions of the unconscious are also implicated in the logic of prophecy that Daniel's story fulfills. His desire to affiliate himself with the Jews coincides with his rescue of a Jewess and his discovery that

\footnotetext{
${ }^{17}$ Eliot would have known that "the mighty drama" of the American Civil War was less noble than here represented: the War between the States divided families, while the British government, if not the millworkers, stood by the slave states for much of the war.

${ }^{18}$ One of the figures Gwendolen considers representing in her tableaux vivants is Briseis, a woman sacrificed between men, a "Yea or Nay" of war in The Iliad. Such roles are drawn up from "Greek wickedness" or "Christian wickedness" to remind us of the woman's cultural destiny, and that these dramas are not, as Rex suggests, "all gone by and done with" (90).
} 
he was born a Jew; these correspondences seem to point to the function of a racial destiny regardless of individual will.

Like many of her contemporaries, Eliot was eager to locate a medium of cultural transmission beyond conscious action by individuals. The concept of racial memory as such a medium took different forms in the writings of Pater and Yeats, for example, as well as in Samuel Butler's Unconscious Memory (1880), which was particularly influential on the modernists (I. Bell 181, 191-95). In a late essay, Eliot denies that actual transmission through "tradition or identity of descent" is necessary to explain analogies between cultures; human nature, or a racial unconscious, is the common element (Collins 387-90). Accordingly, Deronda responds to the story of his mother's effort to obscure his Jewish origins with "a latent obstinacy of race"; she, in contrast, acted on the belief that one can design oneself regardless of origin: "I was not like a brute, obliged to go with my own herd" (698). Yet the law of the father forces her to complete the original narrative: "Events come upon us," she says, "like evil enchantments; and thoughts, feelings, apparitions in the darkness are events. . . . I don't consent. . . . I obey something tyrannic" (693). The tyrannic events of her unconscious, the "spots of memory" (699), compel her to fulfill the collective destiny of her people, not her own ambition.

For Woolf, in the age of Freud, the throng of desires trampling the dead has gained uncanny familiarity. Woolf and her friends in Bloomsbury alternatively viewed the potential for "group consciousness" as a positive unanimism or a sinister herd instinct (McLaurin, "Consciousness," 36-38). In "The Leaning Tower" (1940), Woolf places Eliot and the Victorians (rather implausibly) in an age of faith, when the classes of society resembled motionless, unconscious herds in "separate fields." But 1914 changed all that, and writers were compelled "to tell . . . the unpleasant truth," "analysing themselves honestly, with help from Dr. Freud" (CE 2: 164-66, 177-78); the war raised more alarming visions of herd instinct as a force, in Nietzsche's terms, to "wreck the ... f faith [of the community] in itself" (Good and Evil 113). In the pastoral setting of Pointz Hall, Freudian analysis is under way, though the herd instinct is still contained in separate fields by a lingering feudal order. The Olivers and their guests seem able to hear each other's thoughts, as they become members in an ancient yet avant-garde chorus composed by an anonymous author in collaboration with a herd of cows. ${ }^{19}$ Dreamlike fragments of overdetermined

\footnotetext{
${ }^{19}$ Woolf's longtime interest in interpersonal consciousness intensified in late years, informed by a reading of Freud's Group Psychology during 1939-40, in connection with "The Leaning Tower," "Thoughts on Peace in an Air Raid," and "Anon" and "The
} 
narrative-_Papa's beard," "Mama's knitting," "how Mira's slipper got lost in the mud" - could alert the community to the psychopathology of everyday life, and indeed Miss La Trobe has instigated some self-analysis in the audience: "Did she mean . . . the unconscious as they call it? But why always drag in sex" (159, 174, 199).

In both novels the ominous romantic comedy of English upper-class society appears to be guided by unconscious desires and racial destiny; a customary separation of the spheres-men fight, women sufferand a lingering social hierarchy mask a fierce universal kinship. The "megaphonic, anonymous" narrator of the pageant warns, "A tyrant, remember, is half a slave"; someone in the audience concurs, "We all, I admit, are savages still" (BA 187, 199). But this negative common life is irredeemable without some vestige of hierarchical difference. Who but a messiah or goddess could restore life after bloodshed? The redemptive influence will come, as legend has it, from among outsiders. Perhaps "the ancient consciousness of woman . . . for so many ages dumb" ("GE" [1919] 159), the collective history of the oppressed, will be able to repair the social web, mitigating harsh conditions in the spirit of Victorian reform. ${ }^{20}$ But can outsiders be trusted to treasure the same goods as their oppressors? Women, like the masses, are reputed to encompass the best and worst of human impulse, the power to create new life and the urge to trample the dead in vengeance. What will happen if the marginalized are permitted to act?

A resurgence of the feminine common life, instead of preventing holocaust, might smash every structure in sight. Culture requires boundaries as speech requires silence, and Woolf almost as much as Eliot admits the need for certain traditional boundaries. "A few were chosen; the many passed in the background," as the sentimental Rev. Streatfield puts it (BA 192). In To the Lighthouse, Mr. Ramsay poses the riddle of the relation between the elite and the unchosen:

Reader" (Silver, Notebooks, 115-16). In "The Leaning Tower," she sides with her audience of workers: Arnoldian culture would soon topple, she argued; writers must now "write the common speech . . . share the emotions of their kind" ("The Leaning Tower," CE 2: 169-76).

${ }^{20}$ That Woolf is still intrigued by Eliot's vision of feminine reforming influence is suggested by a passage in "Notes for Reading at Random" (a projected literary history written concurrently with Between the Acts): "The song making instinct. The map of London. Alfred Tennyson, Mrs GH Lewes had suggested: a meeting was held in March . . . in Gower St. at 8. This is continuity-the [extension] certain emotions always in being: felt by people always" (Woolf's ellipses; Silver, "Anon,' " 373-74). Here Eliot (in her guise as Victorian lady reformer) might be getting up a committee to restore the music of humanity. These cryptic notes condense several elements of Woolf's vision at this time: first, the origin of art in instinctive song or ritual; then spatial history (such as a map of London or a country house near the Roman road); then nostalgia for Victorian faith in fellow-feeling. 
Does the progress of civilisation depend upon great men? Is the lot of the average human being better now than in the time of the Pharaohs? Is the lot of the average human being . . . the measure of civilisation? Possibly not. Possibly the greatest good requires the existence of a slave class. The liftman in the Tube was an eternal necessity. The thought was distasteful. . . . He would argue that the world exists for the average human being; that the arts are merely a decoration imposed on the top of human life. (67)

The very hierarchy that uplifts art must oppress those who are left underground, and Eliot and Woolf cannot naively accept Mr. Ramsay's democratic solution to the riddle: there remain tensions between the chosen passengers and particular liftmen. Yet they would only have agreed up to a point with Nietzsche's claim that cultural advance "needs slavery" (Good and Evil 201); Western civilization and myriad forms of oppression have evolved in tandem, but such guilty "progress" must be, will be arrested whatever the loss.

Both novels strike an uneasy compromise between the cultivated characters and the "people." Daniel, for example, can only redeem his people by abandoning Gwendolen and Leonora Charisi as princesses in exile; he must reject the godforsaken European present much as the author spurns readers unwilling to follow an arid argument on Zionism. Similarly, Miss La Trobe can revive English literature for the people only by staging a kind of Reader's Digest literary history that ironically repels and scatters the audience, holding up mirrors to their isolation and puzzlement. Further, the characterization in these works reflects little love of ordinary people, who are often vulgar like the Cohens and Mrs. Manresa, or snobbishly parasitical like Vandernoodt or Mrs. Parker. To accept humanity must be to welcome all these to one's estate, though heroism, greatness, the very foundations of civilization may have depended on selectively closing the gates. Deronda's uneasy condescension to the Cohens resembles that of the Olivers to the villagers at the tea ceremony ("few, it is to be hoped, will be offended to learn" that "the entire Cohen family" were invited to Daniel's wedding [88o]). The Jewish people Daniel sets out to lead, however, like the costumed laborers whose song is wafted away from the audience of the pageant, form a soft-focus ideal of a common humanity.

If culture must necessarily exclude in order to survive, it does so at the peril of its own self-understanding, which in turn is essential for survival. The final novels would like to affirm that art promotes such self-understanding in the average human being, whether tyrant or 
slave; from this perspective, "we" are allied (in spite of lingering racism and classism) with the anonymous liftman as collaborators, instead of being "great men" served by a slave class (thus Miss La Trobe, "a slave to her audience," "worked like a nigger" to produce the Victorian age [94, 150], yet the audience and actors are her minions, in a sense distributing her authorship). "We" are dispersed the moment we speak this desire for unity; some must be chosen to lift our common brutality toward divinity. Vain as such aspirations can be in these novels, both works implicitly concur with J. S. Mill's belief that, "in a good and a bad sense, the English are farther from a state of nature than any other modern people" (124). It is a question of salvaging the virtues of this advancement-through the pan-culturalism of aliens like Daniel or Miss La Trobe-while braving a return to forgotten origins in order to prepare for the next act.

Besides invoking the ritualistic origins of art, these novels retrieve forgotten beliefs from a collective pantheon; ancient religion becomes another means of sustaining meaningful continuity. Woolf's novel is characteristically more varied and elusive than Eliot's in its deployment of a sacred heritage, and it implies more heterogeneous historical narratives. Incorporating prehistory, Woolf also alludes to archaic Christianity alongside Egyptian and Greek mythology, constructing an elaborate analogical machinery in the modern style, as though Between the Acts were a Ulysses with a bias toward matriarchal myths. Eliot also draws on pagan mythology and Christian hagiography, without conspicuously preferring female deities; these allusions might appear to be a matter of cultivated habit rather than subversive design. Yet at the same time, Eliot engages Judaism as a living religion, not just a convenient source of imagery for the secular cosmopolitan. Even the apparently casual association of characters with sacred legends, such as the comparison of Gwendolen to Calypso, reveals an earnest intent, an argument about women's destiny. Woolf plays with typological characterization even more earnestly, turning similitude into surreal identity: her ladies and gentlemen are pagan deities or Christian saints, just as her villagers claim to be figuresfrom English history.

Corresponding to this difference in characterization between Eliot's intelligible metaphors and Woolf's perverse allegories, different modes of interpretation are invited by these works according to their favored systems of belief. Daniel Deronda replicates the Mishnah and the Gemara of the Talmud, overlaid parallel commentaries denoting a history of response to a text nevertheless affirmed to have been revealed for all time. In contrast, the segments of Between the Acts might be the broken panels of an Egyptian monument, an edifice that 
calls for a kind of three-dimensional hermeneutics: it must be entered and lived in before the inscriptions yield their meaning (Brockett 13). To our Western minds, the Hebrew text remains comparatively decipherable, whereas the ancient matter of Egypt has no continuous tradition of commentary. Yet the collaborative exegesis of Miss La Trobe's pageant, itself a form of literary criticism, resembles the Rabbis' polyphonic commentaries, which have never known any detail to be insignificant or any reading to have the last word. ${ }^{21}$

Why should the women of letters have been attracted to the ancients and to alien forms of thought and belief? Certainly this attraction was common enough in literary and intellectual circles throughout their lifetimes (Jenkyns; Vickery). Evelyn Haller, to whom I am indebted for an understanding of Isiac mythology in Between the Acts, maintains that Woolf adopted the Egyptian myth of Isis because "Egyptology" "undermined the Victorian world view" and because Egyptian mythology subverted "imperialism, Christianity, and patriarchy" ("Isis" 109-10). But Egyptology was an expanding horizon in the worldview of many Victorians, including Eliot, and for many it was an extension of the British empire of reason as well as imagination (Paden). Woolf owed her acquaintance with things Egyptian to explorations begun by Victorians. ${ }^{22}$ In her attraction to a civilization more alien than the early Christian or classical Greek, Woolf was very Victorian as well as modern: "Neither one thing nor the other; neither Victorians nor themselves," says the audience in an Arnoldian mood (BA 178; see "The Leaning Tower," CE 2: 176).

The drive to coordinate alien mythologies in a universal cultural history was well under way when Eliot came to intellectual maturity (she satirized that drive in her portrait of Casaubon), and it survived the growing doubts about the foundations of the self, of knowledge, and of empire. Works such as Harrison's Ancient Art and Ritual and Frazer's The Golden Bough grew out of the Victorian quest for origins and cultural consensus, and influenced younger generations of writers in turn. ${ }^{23}$ Thus Woolf became intrigued by the Egyptian cult of Isis,

\footnotetext{
${ }^{21}$ Like biblical narrative, Woolf's is laconic, "fraught with background," as Erich Auerbach would have it (12); her last novel exhibits the repetition of words and action, the stress on dialogue, and the absent narrator of biblical texts as described by Robert Alter $(21,178-85)$. Eliot more nearly approximates the surface elaboration of Homer than the spare action of the Bible (Handelman 29-33).

${ }^{22}$ As Haller herself points out, the Egypt Exploration Fund was established in 1882, the year of Woolf's birth (Haller, "Isis," 109-10); an eminently Victorian enterprise, it began only two years after Eliot's death.

${ }^{23}$ See Vickery. Eliot would have recognized Harrison's assumption that present-day rituals among European folk or exotic tribes could be "read" as historical records (Harrison 126). See "The Natural History of German Life" (1856) 274-75. Woolf read
} 
which had already attracted Eliot's speculations (her notebooks for Daniel Deronda record references to that cult [Baker, Eliot Notebooks, 1: 156-6o]). Eliot appears more interested in the Hellenic myth of Persephone, a narrative that downplays the questing role of Isis, but that implies the mother's power in the Eleusinian mysteries; Woolf repeatedly draws on the Demeter-Persephone narrative, particularly in To the Lighthouse (Pratt 150-53), and it resurfaces at times in her last novel.

Woolf's innovation on Eliot's use of ancient belief, then, lies not in the direction but in the extent. Woolf undertakes the kind of excavation that Freud performed in Moses and Monotheism (published by Hogarth Press in 1939, during the writing of Between the Acts [Beer, Past, 164]). Not only is your Christianity founded on Judaism, she seems to say with Eliot, but that Judaism itself grows out of Egyptian cults, she seems to add with Freud. Yet Woolf has not left Eliot's perspective far behind. No evidence that we could present of the historical layering of beliefs would have surprised Eliot. In light of German historical criticism ("Evangelical Teaching" 171), without nostalgic faith, the biblical scriptures become "simply the history and literature of a barbarous tribe that gradually rose from fetichism to a ferocious polytheism, offering human sacrifices, and ultimately, through the guidance of their best men, and contact with more civilised nations, to Jehovistic monotheism" ("Introduction to Genesis" 257-58). Her last novel would add another clause here: "Through contact with English humanism, it will finally rise to an enlightened Zionism." Judaism cannot claim a unique providential progress if it is repeatedly influenced by "more civilised nations," not only the British but the Egyptians long before. The notebooks for Daniel Deronda suggest that Eliot wished to impart to the English a sense of all time-honored beliefs, not just Judaism, including the matter of Egypt that Woolf was to emphasize in Between the Acts. ${ }^{24}$

subsequent anthropology, including Ruth Benedict's Patterns of Culture in 1940 (VW Diary 5: 306). Harrison emphasizes Isiac ritual and the kinship of dying god myths as well as totemistic beast-dances (15-20, 46).

${ }^{24}$ Eliot noted, as Freud later did, that "Moses" was an Egyptian name meaning child, suggesting that the Jewish leader (not unlike Daniel) might have been Egyptian by birth and religion as well as upbringing (Baker, Eliot Notebooks, 3: 51); Eliot may have derived this fact from a guidebook for a possible journey to Egypt in 1874 (Baker, Notebooks 3: 196-97n.1); Haight 473-74. See Freud, Moses and Monotheism, 5. Freud kept a statue of Isis as well as Athena on his desk. Eliot's commonplace book probably dating from 1868-69 quotes the Egyptian Book of the Dead, as well as European and English poets and Hebrew scripture on the lasting fame of the prophet or poet (Waley). Another notebook records numerous entries on the role of Egyptian women, who were better off than women in other ancient societies (Wiesenfarth, Notebook, 6-7). 
Neither author is plundering ancient myths merely out of scholarly curiosity, of course. For them this is an archaeology of the self and its gendering in contemporary civilization. In spite of the thunder of Jehovah in Eliot's text, mythology and saints' legends can be heard murmuring of an ancient consciousness of women's suffering. Similarly, though Woolf, like male modernists such as Yeats and T. S. Eliot, recalls the myth of a dying god (Vickery 230, 256), she does so to revise the heroic archetypes that subject women, and subtly honors female divinity. ${ }^{25}$ Instead of the myth of Persephone, who like Gwendolen is the mother's periodic hostage to a male power, Woolf engages the myth of Isis (or Isa), a life-giving goddess, consort of the dying god, who gathers the limbs sundered by his monstrous male rival and restores him in the seasonal rebirth of the Nile, their son. The myth of Isis offers an alternative to, though not a complete escape from, the woman's tale of rape and captivity; it incorporates female agency in what is nevertheless a succession from father to son. And as Isa's meditation on rape and the recurring refrain of "sister swallow" suggest, violation and silence are ever-present threats in narratives about women or goddesses. ${ }^{26}$

The dramatis personae of these novels are types drawn from many of the same myths and legendary histories. Characters in both novels discover within them an "unacted part," the original type "lost-inthe-mists-of-antiquity" (BA 153, 190). ${ }^{27}$ Whereas Eliot relies on the messianic hero and counterbalances the worlds of Daniel and Gwendolen as "equivalent centre[s] of self" (M 157), Woolf multiplies such centers in an unheroic group. The results of these authors' archaeological labors should be displayed in the context of each novel to suggest

\footnotetext{
${ }^{25}$ According to Freud, the earliest traces of religion suppress not only the murder of the patriarch by sons wishing to possess the mother but also a matriarchal phase that succeeded that murderous rebellion; the worship of a ritually slain animal-totem commemorates the slain patriarch (and is one source for the myth of a dying god [Moses and Monotheism 104-11]).

${ }^{26}$ "Isis becomes a swallow to search for her . . . husband," as Haller notes ("AntiMadonna" 104), but the swallow is also Philomela, the sister of Tereus's wife Procne, who is tricked into marrying Tereus (a rape); when Philomela threatens to tell, he cuts out her tongue, and she weaves a tapestry of the tale for Procne to see. In revenge, Procne kills Tereus's son, and the sisters escape; the raped and mutilated sister (creator of a text) becomes the swallow, and the murderous wife becomes the nightingale, able to sing (Hamilton 270-71).

${ }^{27}$ See Frye on the use of typology to lend "meaning and point to history" (Code 8081). Landow distinguishes Eliot's "allusive literary iconography" from biblical typology $(3,107)$. Yet there is secular typology in these final novels. If Moses is the type of Christ, he is the antitype of Osiris, and Daniel himself can be introduced in this series. Eliot discounts the privileging of Christ as the one messiah, the one typological meaning: Daniel is both antitype (a second Moses) and type of the messiah still to come (Pykett 68).
} 
their implications for a feminist revision of history. The overlaid types and cultural histories in these works uncover contemporary versions of an ancient sexual division of labor. While webs of allusion surround the male characters, the women seem endowed with the most ancient consciousness, the most "unacted" parts.

\section{Sexual War and Unconscious History in Daniel Deronda}

When Eliot encrusted the figure of Dorothea Brooke with such gems as "Saint Theresa" and "Ariadne," or that of Gwendolen Harleth with "Saint Cecilia" or "Lamia," she was not just displaying knowledge or adorning a tale. She was both exalting her unknown women as historical "types" and challenging the unique truth of modern accounts of civilized society. Allusions to saints' legends and mythology pervade English literature, of course, but Eliot brought to English fiction a new level of learned encoding, outdoing her contemporaries as at times Woolf would outdo hers. ${ }^{28}$ For the women writers, an encyclopedic display of "all mythologies" might lend superhuman powers to a heroine or it might reveal recurring patterns of female sacrifice and expose depths of delusion in empiricist versions of contemporary reality. The pavement underfoot, the foundation of knowledge, is porous, as Dorothea realizes in visiting the necropolis of "visible history," Rome (M 143); this heroine might be sharing in one of Woolf's moments of alienation in Whitehall, or one of Lucy Swithin's visions of mammoths in Piccadilly. The forms of polite society disguise the resemblance of a husband to a minotaur; indeed, you and I might be grotesque metamorphoses of the divine and base. Hence Eliot's mythological subtexts in Daniel Deronda reveal unseemly intimacies and conjunctions beneath a Victorian faith in the differences that ground social order and progress. The confident distinctions between such enterprises as sports, courtship, and international conquest, like those between Englishmen and animals or Englishmen and Jews, break down as characters reveal thronging multitudes within them.

\footnotetext{
${ }^{28}$ Anna Jameson, the famous Victorian woman of letters and feminist, popularized art history and added to the repertoire of heroic female parts (e.g., Shakespeare's heroines as role models). Her Sacred and Legendary Art furnished Eliot with saints' legends and iconography for her heroines in Romola, Middlemarch, and Daniel Deronda (see Wiesenfarth, Notebooks, 58-68, 183-88). The Brontës and Christina Rossetti exploited the subversive power of fairy tales in much the same way, but without claiming learned authority.
} 
The focus of many of the superstitious distinctions of society is the young English lady, whose profession is to enact her difference from a raw female and from a man. Like Isa Oliver, Gwendolen Harleth is especially burdened with a fateful repertoire of roles; very up-todate, she is full of rebellious desires that unconsciously hark back to primitive practices. Gwendolen appears as a "young witch" (127) of "demon ancestry" (99), with prophetic dreams and phobias, and an uncanny malevolence toward suitors; she is also "a perfect Diana" (199) transformed into a Persephone $(824,831)$ : from huntress to victim.

Unlike Dorothea Brooke, Gwendolen deliberately poses as a saintand the vain posing mocks the likeness. When she sits at the organ in their new house and cries, "Someone shall paint me as Saint Cecilia" (the patroness of music credited with inventing the organ [55]), she seems to be displaying her accomplishments, but she also reveals her ignorance and profanity. In her mother's "black and yellow bedroom," where she has a "pretty little white couch . . . by the side of the black and yellow catafalque known as the 'best bed' " (the colors of death, marriage [and jealousy], and purity respectively, Anna Jameson tells us [1: 36-37]), Gwendolen poses before the mirror and says, "I should make a tolerable Saint Cecilia with some white roses on my head . . . only, how about my nose, mamma? I think saints' noses never in the least turn up" (56-57). She is right at least that she misrepresents the saint, who according to Jameson should be shown in an aesthetic rapture, with "an expression of listening rather than looking," and her crown of heavenly roses "should be red and white, symbolical of love and purity" (her emphases; 2: 594-96). Loving only her mother (who has shown that marriage is a kind of death) and the image in her own mirror, Gwendolen lacks precisely the loving devotion to music of the saint or of Herr Klesmer. Her association with white ("Gwen" means white) will be threatened by a deadly and jealous marriage, but she will continue to desire her own chastity and freedom like Gwendolen, the Welsh Diana (the "Lady of the bow" and goddess of the moon). ${ }^{29}$

This sort of subtle criticism of the heroine's egotism and sexual subjection is carried on throughout the novel. Gwendolen parades before the company at Leubronn like a "Nereid in seagreen robes" or

\footnotetext{
${ }^{29}$ The goddess Gwendolen corresponds with Venus as well as Diana, and her story shares the pattern of Greek myths. She was a queen deserted by her husband for another woman; she made war on her husband and killed him, and she drowned his mistress and their daughter. Eliot's source here is another contemporary woman of letters like Jameson, Charlotte M. Yonge; Wiesenfarth, Notebooks, xxxvi; Baker, Eliot Notebooks, 1: 101-2; Introduction 36-37.
} 
a "Lamia" (40-41) — suggesting a blend of the animal and divine that endangers men. Indeed, she seems to tempt a "revival of serpentworship" as though all desired women invite idolatry. These images implicate sexual politics: "Why should not a woman have . . supremacy" like a man $(39,47)$ ? This is Gwendolen's question as well as the slimy Mr. Vandernoodt's, and thus implicitly a misguided one, but we find the narrator also questioning the idea that only men rule supreme. Gwendolen's greater likeness to a pagan goddess than a Christian martyr parallels her endeavor to be a ruler rather than a subject.

Many critics of the novel have recognized currents of political metaphor as well as animal imagery in Gwendolen's relations with Grandcourt; both clusters of allusion add to the heroine's goddesslike function as a primitive resistance to patriarchal tyranny, while they challenge the civilized pretensions of modern England. Gwendolen is a "princess in exile" ruling a "domestic empire" because of "her inborn energy of egoistic desire" that commands others' fear; in this respect she is exactly like "a very common sort of men." "Who is so much cajoled and served with trembling by the weak females of a household as the unscrupulous male . . . ?" (71). Though the narrator thus places Gwendolen in the father's position as pinnacle of the household pyramid, this placement does not render the issue of egotism identical for both sexes; in the end, all the women of Offendene become Grandcourt's subjects. He exercises "triumphal diplomacy" such as could "govern a difficult colony" $(645,655)$ to compel his wife to act her part. The supreme imperialist, he makes the world his cheerless home (whereas the women and the Jews all experience exile); he has none of the fear of doing harm that ultimately saves Gwendolen from the hell of egotism ruled by this plutonic gentleman $(71,509)$.

In spite of parading as huntress ("My arrow will pierce him before he has time for thought," she imagines before meeting Grandcourt [127]), Gwendolen unconsciously understands her role as huntsman's prey or explorer's prize. In her first conversation with Grandcourt, she even echoes the horticultural imagery of the Victorian debate on women's education, and neatly links it to imperialism and Egyptology: "We women can't go in search of adventures-to find out the NorthWest Passage or the source of the Nile, or to hunt tigers in the East. We must stay where we grow, or where the gardeners like to transplant us. . . . That is my notion about the plants: they are often bored, and that is the reason why some of them have got poisonous." At this moment, though Gwendolen flatters herself that she is a powerful huntress, Grandcourt's "lotos-eater's stupor" has begun to poison her, turning 
her into a "statue" gripping "the handle of her whip"—an inanimate figure of vain desire for power. She can only try to escape by pretending to drop her weapon (171-72). Gwendolen's bloom, her ignorance, is indeed deadly, as it subjects her to a predator almost as ignorant yet wholly without bloom, and all the more deadly because he appears to be the English heroic type.

In the savage sport of courtship, females fight as hard as males, and perhaps with more conviction. If slaughter bores Grandcourt, Gwendolen has a zest for the kill. For instance, she thrives at the archery meet, itself a disguised marriage market:

The time-honoured British resource of "killing something" is no longer carried on with bow and quiver; bands defending their passes against an invading nation fight under another sort of shade than a cloud of arrows; and poisoned darts are harmless survivals either in rhetoric or in regions comfortably remote. Archery has no ugly smell of brimstone; breaks nobody's shins, breeds no athletic monsters.

Maidens may take part in archery (though they should not fox-hunt) because of a conspiracy of forgetfulness, yet Gwendolen, lady of the bow, is half aware of her warlike desires. Though men objectify her either as an animal to be tamed ("a high-mettled racer") or a creature who turns men to animals-a "Calypso" (134)—she figures herself as masterful subject: she "wished to mount the chariot and drive the plunging horses herself, with a spouse by her side who would fold his arms" (173). Grandcourt, however, is more successful in turning humans to brutes: he torments his dog Fetch as he would a jealous woman, and treats his factotum Lush like a superior pet whom "he might kick . . . only he never did choose to kick any animal" (161, 164). He hunts a spirited woman "worth his mastering" (195) and soon manages "his wife with bit and bridle" (744; Hardy 226-29). Grandcourt's perfect demeanor and respectability mask the misogynist brutality condoned by genteel practices.

Eliot insistently associates this agent of civilization with primitive stages of evolution and with the underworld. In the opening scene of Daniel Deronda, Gwendolen has fled this suitor to enter a "gas-poisoned" gambling hall full of "human dross" with "crab-like hand[s]" or heads like "a slight metamorphosis of the vulture," all "specimen[s] of a lower order" to which Gwendolen, though decked out like a "serpent," believes herself superior $(36-40)$. Grandcourt himself is another throwback: his "sudden impulses ... have a false air of 
daemonic strength . . . though perhaps their secret lies merely in the want of regulated channels for the soul to move in- . . ducts of habit without which our nature easily turns to a mere ooze and mud" (194). What is civilization if it is ruled by a creature of the primeval slime or a "handsome lizard of some hitherto unknown species" (17374)?

Clearly it is hell for Gwendolen, who in widowhood imagines a return to her mother's bucolic home as a return to paradise "after following a lure through a long Satanic masquerade . . . end[ing] . . . in shrieking fear lest she herself had become one of the evil spirits who were dropping their human mummery and hissing around her with serpent tongues" (831). ${ }^{30}$ In spite of her "human mummery" of innocent beauty, she has proved as satanic as her husband, king of the underworld; she may have too high a voice for tragedy, as she once playfully observed, but in her soul lurks vengeance. ${ }^{31}$ Her wish for Grandcourt's death is magically realized; forced to be passive, she nevertheless can feel simultaneously "the outlash of a murderous thought and the sharp backward stroke of repentance" (72), between the acts, as it were. Gwendolen becomes a vessel of women's ancient, demonic rage against their abductors.

Leonora Charisi also reenacts a perpetual animosity toward ruling men. Feminist readings of Daniel Deronda readily point to this woman artist's resemblance to Eliot herself, but her similarity to Gwendolen is less obvious. Neither Gwendolen nor the Alcharisi has "felt exactly what other women feel—or say they feel" (691); their ambition belies the enforced selflessness of womanhood. In a passage that in many details recapitulates the opening encounter between Daniel and Gwendolen, Eliot introduces the mother as a mysterious creature of appearances (her son might again ask, "Was she beautiful or not beautiful?"); she is likened to Melusina, another enchanted, half-serpentine woman like Lamia. Leonora is more august than seductive, a figure of royalty capable of encompassing "myriad lives in one," appearing to Deronda like "a mysterious Fate" or "a sorceress" (687-

\footnotetext{
${ }^{30}$ The home of Grandcourt's mistress, which he vindictively wills to his wife, is "purgatorial," though it "would be a paradise" if one were in the coal business (83031). Not only is Persephone's return to a green world suggested here, but also Dante's pilgrimage. Deronda seems a Miltonic archangel to Gwendolen, and Milton presides over the novel at the last: the final words of the novel, from the ending of Samson Agonistes, bless the death of Mordecai.

${ }^{31}$ Gwendolen frequently wants to play-act; she compares herself favorably to the tragic Jewish actress, Rachel: "The more feminine a woman is, the more tragic it seems when she does desperate actions. ... As if all the great poetic criminals were not women! I think the men are poor cautious creatures" (84-85).
} 
$89,723)$. The epigraph to chapter 51 fittingly presents the Greek poet Erinna, figured here as a Lady of Shalott who must spin unintelligibly and repetitively "while the throng / Of gods and men wrought deeds that poets wrought in song." Left out of the advancing tradition like another Maggie (or Hecuba), the woman is denied original authorship (Rosenman, "Women's Speech," 238, 244-46). Leonora has sought revenge in a career of deeds and song that defies male authority (and the epigraph to chapter 53 links her to Shakespeare's Cleopatra). She claims that "a great singer and actress is a queen," but her power is only temporary, as patrilineal descent restores order: "She gives no royalty to her son" (697). Instead, she can only become a princess by marriage, fulfilling the obscure tasks of the domestic woman. She ends with a blasphemous will to die that contrasts with Gwendolen's frail but devout willingness to live.

Daniel must fulfill his destiny as an exiled prince who founds his own country, at the cost of abandoning these two imperious goddesses, as though they represent the idolatry that the chosen people must spurn, the goddess-worship that patriarchal monotheism historically supplanted. Yet Eliot portrays Daniel as deserving to lead because, unlike Grandcourt, he cares for the suffering of women and other underlings and he wants to know history; he is not the English Philistine, xenophobe, and misogynist. Daniel stands apart from the Grandcourts' malingering British materialism, a kind of polytheism without the creed. On a tour of the abbey, for example, Gwendolen and Grandcourt weigh the value of their future possessions, whereas Daniel senses a history of belief recorded in such features as the old choir turned into a stable; here Daniel unconsciously bares his head. " 'Do you take off your hat to the horses?' said Grandcourt, with a slight sneer" (473-74). The well-bred Englishman, Grandcourt participates in a cult of horseflesh, but he has no trace of genuine reverence and has forgotten history.

Daniel's polymorphous reverence saves him from Grandcourt's ruthless egotism, but it also presents a danger: he too might lack the channels that prevent a reversion to ooze and mud. Full of suffering and sensibility, Daniel takes a kind of historical interest in saving women, but he must resist the barbaric practices subtly associated with them. Until properly schooled by Mordecai, Daniel confuses the allure of the past with decadence and idolatry: "the heaping of catmummies and the expensive cult of enshrined putrefactions" (414). This is a strange necrophiliac temptation, and it coincides with his fascination with self-destructive women (both Gwendolen and Mirah 
catch his attention as spectacles of doom, but Mirah is attempting to drown herself, whereas Gwendolen will later "drown" her husband). Mr. Vandernoodt teases Daniel for being more interested in an "antedeluvian . . . scandal about Semiramis" ${ }^{\prime 32}$ or "a lady [with] a rag face and skeleton toes" (488) than in the gossip about Grandcourt's abandoned Medea, Mrs. Glasher. Such allusions point to the sexual betrayal of women (a very old story), but also suggest that Daniel more readily desires a victim with a long history than a full-blooded woman with a future. He joins a male apostolic succession, with a helpmeet who does not stand for a competing deity. ${ }^{33}$

If it is possible to construe Daniel's vocation-which the author appears to take very seriously - as a means to elude a threatening suitor, Gwendolen (who has made her own escape to Leubronn), it appears that Gwendolen's power to determine the Yea or Nay is great indeed. Gwendolen's flight from Grandcourt is futile, leading to hell, whereas Daniel's escape from her is said to lead to a new paradise. The contest of wills between heroine and hero at the end appears like a battle of titans, a test of the ultimate force of patriarchy. When Daniel announces his plan to found a Jewish homeland, Gwendolen's fear of horizons and her superstition are confronted with the historical world and religious duty. The passage, recalling the more famous depiction of girls as vessels of human affection in the midst of men's battles, implies that all the violence of age-old myth and contemporary war lurks within the imagination of the woman suddenly forced to abandon her egotistical hopes.

The world seemed getting larger round poor Gwendolen, and she more solitary and helpless. . . . There comes a terrible moment to many souls when ... the larger destinies of mankind, which have lain aloof in newspapers . . . enter like an earthquake into their own lives-when the slow urgency of growing generations turns into the tread of an invading army or the dire clash of civil war, and grey fathers know nothing to seek for but the corpses of their blooming

${ }^{32}$ In "Notes for Reading at Random," Woolf refers to "Semiramis- . . . Aspasiawitches \& fairies," that is, ancient women of power and learning; Silver links this reference to Woolf's observation that anonymous poets were often accused witches (RO 50-51; Silver, "'Anon,' " 371, 374).

${ }^{33}$ Daniel's mission is distinguished from that of a woman like Fedalma, who is chosen to renew her race in The Spanish Gypsy, by the fact that it does not entail a forfeiture of family life: a man may combine ambition and romance plots, but clearly only a chastened romance with a sisterly, self-effacing woman. Egyptian mummies are dangerous to one who would reconstitute Judaism. 
sons, and girls forget all vanity to make lint and bandages which may serve for the shattered limbs of their betrothed husbands. Then it is as if the Invisible Power that has been the object of lip-worship and lip-resignation became visible, according to the imagery of the Hebrew poet, making the flames his chariot and riding on the wings of the wind. . . . Often the good cause seems to lie prostrate . . . the martyrs live reviled, they die, and no angel is seen holding forth the crown and the palm branch. (875)

From one point of view this passage recollects biblical rhetoric chastising those who see with "the eyes of frivolity" (876), rebuking women as well as nations for imputed wantonness; they must be taught the true religion of selflessness and racial destiny. From another angle, this is a passage of indirect interior monologue; the imagery of carnage seems drawn from the racial unconscious as it emerges in Gwendolen. The fathers and girls seem to enact myths of the dying god (as Isis rebinds the shattered limbs of her husband, and Osiris recovers his son Horus); as in those myths it is never clear that the mourners are not also the murderers.

The passage unleashes rage against man, the prostrated good cause; it suggests that Gwendolen's murderous wish turns now from Grandcourt to her unresponsive mentor. No angel relieves Gwendolen's torment in this final encounter, but none is sent by her to relieve Daniel's: his "anguish was intolerable. He could not help himself. He seized her outstretched hands . . . and kneeled at her feet. She was the victim of his happiness." Like so many heroes before him he must abandon the victim that he appears to worship, and she must join the suppressed ancient consciousness of woman. She has become a seated Fate like his mother; she acts her emotions-like the Alcharisi's, the repetitions of tyrannical memory: "A great wave of remembrance passed through Gwendolen and spread as a deep, painful flush over face and neck." Her covertly resistant words indicate the cost of the suppression. " 'Don't let me be harm to you. It shall be better for me-'She could not finish. . . . The burthen of that difficult rectitude towards him was a weight her frame tottered under." (Daniel's mother commanded, "I shall have done you no harm" [727].) Gwendolen's insistent claim that she "will live" may be less obedient than defiant, since she has been condemned to the deadly emotional repetition of a woman's life, to become "a mere speck" in the wide perspective of public history. She will not go gently into that oblivion: "Through the 
day and half the night she fell continually into fits of shrieking" (87579).

We learn, in the ensuing chapter, of the "blessed protectiveness" of Daniel's love for Mirah; his wife will be a "flower in the warm sunlight," like a plant unaware of its greenhouse, and he will soothe her "memories of privation and suffering" with "the sweetest fountains of joy." In this fairy-tale life, she worships him as a "rescuing angel" the angel that does not come to those awakened to the nightmare of history-and she explains away those who are left out (the abandoned Hans and Gwendolen; 879-80). Though Mirah does have a past, and is said to harbor "fervid emotion . . . supposed to require the bulk of a Cleopatra" in her tiny "Psyche-mould" (801), she somehow has nothing to do with cat-mummies. She will reincarnate the biblical matriarchs without recalling any of their affiliations with suppressed deities. The sinister energies that have resurfaced in recent excavations in the East are forgotten when the Derondas depart on their missionary campaign, outfitted with the most modern equipment as though they were only more life-affirming tourists than the Grandcourts.

In spite of this rosy prospect, other forces in the novel do not allow us to forget a past marked by wrongs against women, and hence the threat of revenge. One final example of such a haunting reminder particularly anticipates Between the Acts; it is one of the more prominent of the nightmarish scenes that pursue Gwendolen: the episode of the Whispering Stones. Before this episode we have seen, in Gwendolen's response to the picture of the dead face and fleeing figure, that she shares a gothic heroine's suspicion that civilization itself is haunted. At the archery meet she seems to discover who it is that haunts it: the figure of the wronged woman. The arcadian setting, "an extemporised 'As you like it,' " is a perfect disguise for an encounter between rival women; everyone else but Lush believes the play is about Grandcourt's pastoral chase of Gwendolen. The rendezvous between the hunter's past and present prey takes place at "the Whispering Stones, two tall conical blocks that leaned towards each other like gigantic grey-mantled figures," ominous enough to make "good ghosts on a starlit night" (188). Hearing Mrs. Glasher's claim that she should be Grandcourt's wife, Gwendolen "felt a sort of terror: it was as if some ghastly vision had come to her in a dream and said, 'I am a woman's life' " (190). This is yet another prophecy that she must end in witchlike cursing as other women do. A horrifying return of the repressed is suggested by a pagan worship of stones and ghosts, embodying the unappeased power of abandoned women. Woolf simi- 
larly plays with the uncanny potential of the primitive in a domesticated pastoral. In the final scene of her novel, the Olivers' armchairs become huge nameless rocks at nightfall, like the Whispering Stones by starlight, on the threshold of dreams.

\section{Between the Acts of Sexual War in Modern Memory}

Much of the historical drama of sexual conflict and primitive beliefs in Between the Acts coincides with that in Daniel Deronda, as I have suggested. But Woolf's webs of intercultural allusion are even more extraordinary than Eliot's, weaving in surreal detail a magnified image of the underside of English society. The idea that individuals simultaneously play disparate historical parts has become the core of the action, and the question of possible female supremacy is more emphatically raised. Adultery, rape, and the double standard can be named without melodramatic secrecy-in the newspapers, not behind the Whispering Stones. Yet though Isa is no longer under the heavy guard that surrounds Gwendolen's purity, English upper-class civilization appears much the same tissue of lies that it was; it still channels instincts into sports, it still shores up class and gender hierarchy as well as empire. Many skirmishes in the ancient war between the sexes in the earlier novel are repeated in the later.

As if emulating Eliot's allusions to Saint Theresa or Saint Cecilia, Woolf dresses her characters, particularly the older generation at Pointz Hall, as saints; at the same time, each of the central characters plays a part in the Egyptian myth of Isis and Osiris, disrupting any religious unanimity with compulsive and redundant rites. Lucy Swithin, the most religious figure of the day, is a devout Christian in the guise of an ordinary old widow wearing a cross. But William Dodge wonders, "How could she weight herself down by that sleek symbol?" (73). There is something madly inclusive about "Batty," as the servants call her; her favorite reading is the "Outline of History," about "rhododendron forests in Piccadilly" and "the mammoth, and the mastodon; from whom presumably, . . . we descend" (8-9) ${ }^{34} \mathrm{Her}$ sense of the common origins of all life coincides with her unconscious

\footnotetext{
${ }^{34}$ Compare Rachel's vision in The Voyage Out (67), and Bernard's in The Waves: "The growl of traffic might be any uproar-forest trees or the roar of wild beasts" (W 253); see also Jinny's comment (W 310-11). Woolf supplies Lucy with her own version of H. G. Wells's The Outline of History and A Short History of the World (Beer, Past, 174), but also incorporates Trevelyan's prehistory (see my Chap. 3 above).
} 
function as a composite saint. The morning of the pageant, she gazes at the sky for signs of any covenant between the weather and humanity, and her "eyes glaze[ ]" from superstitious dread of rain; she prays and "finger[s] her crucifix" while her brother blasphemously suggests providing umbrellas (23).

Details of such a passage can be partly accounted for by the kind of search for origins that epitomizes Between the Acts. Saint Lucy, an early Sicilian Christian who met martyrdom by stabbing, is associated with light and the eyes; she is the type of wisdom, represented carrying a knife, a lamp, or her eyes in a dish (Jameson 2: 613-20) - hence the frequent mention of Lucy's eyes. Saint Swithin's feast day (July 15) is believed to determine good or bad weather for the next forty days (roughly the time till the Second World War breaks out) and hence is one source of the preoccupation with rain. Lucy's sainthood readily slips into paganism, as in the odd "consolidating" ritual of cutting bread for sandwiches (the eucharist for the later mass in the Barn?), during which she "held the knife up" and "skipped . . . from yeast to alcohol; so to fermentation; so to inebriation; so to Bacchus; and lay under purple lamps in a vineyard in Italy" (34). The worship of saints is intertwined with pagan superstition, and any village festival descends from the Bacchanal. ${ }^{35}$ The alleged spirituality and childish fancy of women, as well as the supposed lack of appetite in old widows, are made into a kind of literal joke by this multitudinous characterization. Lucy is both as grand and as silly as all folk belief, and she is an influential priestess of the pageant in spite of Bart's mockery.

We have seen that Lucy struggles with her brother in a conflict like that of Maggie and Tom Tulliver, but we are never allowed to identify with Lucy as a heroic martyr like Maggie. If Mrs. Swithin resembles the prophet Mordecai, her heritage is a hodgepodge of symbols and associations. Her one disciple is the homosexual artist-clerk, William, whom she initiates into the household pantheistic faith; she shows him the books like "pan pipes" representing "the poets from whom we descend by way of the mind," and later the nursery, "the cradle of our race," where an image of a dog seems to be worshiped (68-71). But "Old Flimsy" cannot be a Saxon Ezra, it would seem, because she is a woman; even the superfluous Rev. Streatfield has more authority, though his message could be a Swithinian doctrine: "We act different parts; but are the same" (192). Her faith cannot survive in public

\footnotetext{
${ }^{35}$ Lucy's mind may revert to native Sicily here. Her name harks back to Wordsworth's Lucy, "rolled round in earth's diurnal course," much as Gwendolen recalls the indigenous Celtic goddess; the heroines seem to recall a pantheistic faith in natural cycles. Both also affirm feminine purity (as "Lucy" means light, "Gwen" means white).
} 
discourse, but only in orts and scraps of nature and time like Lily Briscoe's "little daily miracles" (TL 240):

Fish had faith, she reasoned. They trust us because we've never caught 'em. But her brother would reply: "That's greed!" "Their beauty!" she protested. "Sex," he would say. "Who makes sex susceptible to beauty?" she would argue. He shrugged who? Why? Silenced, she returned to her private vision, of beauty which was goodness. (205)

Bart's Darwinian and Freudian counter-argument defeats Lucy's Paleyan argument from design, silencing her natural supernaturalism as a threat to patriarchal distinctions. ${ }^{36}$ Lucy is Our Lady of Cycles: "Every morning, kneeling, she protected her vision. Every night she opened the window and looked at the leaves against the sky. Then slept. Then the random ribbons of birds' voices woke her" (206).

If Mrs. Swithin functions primarily as a vestige of primitive Christianity and nature worship, her niece Isa Oliver serves as the goddess Isis, though all central women in the book share the goddess's attributes and none are fixed in a single role. ${ }^{37}$ Just as the first scene of Daniel Deronda, in the hellish gambling salon haunted by human beasts, introduces the heroine as a sinister goddess, the first scene of Between the Acts introduces a modern Isis in a drawing room peopled with beasts and infiltrated by subterranean memories and desires. Mrs. Haines, "goosefaced" and gobbling, objects to discussing "the cesspool . . . to bring water to the village," but readily brings up her buried ancestors. As though participating in the conversation, "a cow cough[s]"; a "bird chuckle[s]" as it devours "worms, snails"; then Mr. Oliver adds his own kind of excavation to those of the diggers of the cesspool, the worshiper of ancestors, and the humanoid animals: a mental archaeology of the "scars made" on the landscape "by the Britons; by the Romans;" and by farmers "in the Napoleonic wars."

\footnotetext{
${ }^{36}$ Between the Acts in many ways recapitulates In Memoriam, as an elegy defying scientific assaults on faith, building up echoing fragments, and concluding with the promise of offspring of a representative couple. Its collective voice is Tennysonian (running into Swinburne): "There's a poem, Tears, tears, tears, it begins. And goes on, $O$ then the unloosened ocean" (BA 200). The recurring songs to the swallow misquote Swinburne's "Itylus" (Maika 29) and recall a song in Part IV of The Princess.

${ }^{37}$ If Isa owes something to Saint Isabel of Portugal, a self-sacrificing peacemaker between son and husband (Attwater), she may also recall James's Isabel Archer (and perhaps Gwendolen and other heroines of the archery match): she aims arrows of jealousy at Giles, whose patron saint's emblem is the arrow (208). On names, see Maika 18-19.
} 
The layers of consciousness, of belief, of history can be stripped away at any moment.

Isa enters ceremoniously, less grotesque than Mrs. Haines, more fluid than earthy, herself a confluence of images for Venus, Juno, and Isis: "like a swan swimming," wearing "pigtails" and "a dressinggown with faded peacocks on it," she comes from tending her ailing son. She desires her guest Mr. Haines, the gentleman farmer, and she imagines moonlit romance with him, floating "like two swans down stream" (3-5); Mrs. Haines is jealous. As a romantic plot sketch, this scene may be clear enough, but its bizarre details can be traced to various myths and rites. The vocation of Isis is to "bring water to the village"; she is associated not only with water, but with the moon and cows (as well as the fish pond, the lotus [or water lily], and the swallow), all of which ritualistically resound in Between the Acts. ${ }^{38}$ In this scene, the swan of Venus, the peacock of Juno, the pigtails and "three-cornered chair" (5) of a seated Egyptian deity, and even the nightingale of Procne form a deliberate mythological confusion mimicking the "astonishing disorder" of our deeply superstitious minds.

Isis is compelled to search (sometimes in the form of a swallow) for her husband-brother Osiris (a kind of gentleman farmer) who has been slain and torn apart each year; she finds him (sometimes in the form of a fish) and restores him to life as her son, Horus (or Isa's son George), representing the waters of the Nile that she has nursed. Haines has given Isa the attributes of Isis, the situla and sistrum, in the form of a cup and a racquet, as Haller points out ("Isis" 119). Throughout the novel, Isa (like others in the family) harps on fish and longs for the inundation at the New Year or summer solstice (as Swithin would bring rain; Haller 116). As "the primeval voice" of cows once saves the pageant from "death . . . when illusion fails," so again Miss La Trobe's work is revived when Isa weeps "all people's tears" in a rain "sudden and universal" (140, 180).

Readers can accept the dream logic of such details without tracing their origins (some would say because we share Jungian archetypes), yet this poetically compressed novel makes new sense when we recall forgotten mythology. Like Gwendolen, Isa plays a woman's age-old

\footnotetext{
${ }^{38}$ See Haule and Smith. Maika's Virginia Woolf's "Between the Acts" and Jane Harrison's Con/spiracy (1987) explicates the symbolism of names and iconography in this novel almost to the limits possible. It appeared after I had completed my original investigation of these patterns (including unprecedented consideration of saints' legends), and it frequently corroborates or extends what I had found; it is a very useful key to the many mythologies in this novel. Maika does not refer to Haller, though Haller's studies appeared before 1984, Maika's first copyright. Who should try to claim originality when we all are thinking in common?
} 
roles in patriarchal narrative and can be either Persephone (155) or "Venus . . . to her prey" (208), victim or huntress, though Isa is more closely allied than Gwendolen to the primitive violence and natural cycles encoded in these myths. Whereas Eliot's heroine generally follows a progression from huntress to victim, Woolf's heroine (always one of many, unlike the star, Gwendolen) performs her multiple parts again and again, more spatially than temporally. The posing for Saint Cecilia or Hermione no longer halts the flow of "real" life; Isa's very existence is a layering of poses and emblematic props.

Still there is a temporal sequence to this narrative: small incidents on the day of an annual festival. The disjointed details look innocent enough. Yet the family at Pointz Hall unconsciously compose medleys on their own roles as deities, Egyptian and Christian. When Isa asks whether the fish ordered for lunch will be fresh coming so far from the sea, Mrs. Swithin breaks in, "'Once there was no sea . . . at all between us and the continent.' ... 'When we were savages,' said Isa." In the ensuing chatter on fish, false teeth, and the incestuous marriages of the Egyptians who invented them, the family uncovers its origins. Bart observes, "The Olivers couldn't trace their descent for more than two or three hundred years. But the Swithins could. The Swithins were there before the Conquest" (28-31). Displaying his own false teeth, Bart shows his resemblance to the fragmented Osiris, while Isa characteristically longs for the fish of Osiris and the waters of Horus; Lucy as usual joins land and sea, like the present and prehistory, and she reflexively recalls the pharaohs, incarnations of these sibling gods. Worship of the male god (here incarnated as the Normans or Olivers) is more recent than matriarchal worship (represented here by the Saxons or Swithins). Certainly Bart lives more in the postVictorian present than Lucy, with his passion for historicist distinctions; "she belonged to the unifiers; he to the separatists" (118).

Every page of this text proliferates more meaning than can be contemplated here. Woolf may have felt an archaeologist's pleasure in constructing a (Joycean?) dig to keep the mythologically minded indefinitely busy. But for Woolf as well as for Eliot, these embedded narratives contribute subtly to an argument about women's fate in history. Isa's longing for the sea is not unlike Gwendolen's wish to set out for "the North Pole" rather than to "do as other women do" (DD 101). In person more cautious than Gwendolen, in imagination Isa is a daring adventurer: "To what dark antre of the unvisited earth, or wind-brushed forest, shall we go now? Or spin from star to star" (51). But Isa no more than Gwendolen has a goddess's power to drive the horses herself. As though replicating Gwendolen standing like 
a statue with a whip and speaking of greenhouse plants with her implacable wooer, Isa stands like a "statu[e] in a greenhouse" beside the hydrangea (or water-vessel), holding a knife as her admirer William Dodge looks on. She continues the play: " 'And from her bosom's snowy antre drew the gleaming blade. "Plunge blade!" she said. And struck. "Faithless!" she cried. Knife too. It broke. So too my heart,' she said." These heroines must self-destructively repeat old romantic plots; whether the ineffectual gestures with whip or knife are aimed at themselves or at the faithless men who would master them, the effect is the same.

Such scenes indicate the remarkably similar sexual theater of these novels, but in the later novel there are some striking variations in the depiction of men as well as women, and a newly explicit attack on phallocentrism. It is no accident that Isa confides in the greenhouse with William Dodge, the homosexual, from whom women "had nothing to fear, nothing to hope" (113). The woman and the gay man may be conspirators, but he does idealize her in her feminine sacrificial role, and he worships the phallus as she no longer does. The legend, according to John Lemprière, recalls that Isis "recovered the mangled pieces of her husband's body, one part only excepted, which the murderer had thrown into the sea" (754), and which, according to Sir James Frazer, had been eaten by fish (2: 10). This part, Frazer is unashamed to explain, was "the genital member," later commemorated in phallus worship (Frazer 10; Lemprière 754), which appears to be revived in William's and Mrs. Manresa's as well as Isa's desire for Giles. Isa's husband is frequently accompanied by a popular song to the phallic hero: "Armed and valiant, bold and blatant, firm elatant" (110); and Mrs. Manresa, "the wild child . . Queen of the festival" (79), "goddess-like, buoyant, abundant" (119), chooses him as her counterpart.

Giles rightly perceives William, the man-raiser's mercurial sidekick, as a threat to that firm ideal; he reviles him as a "toady; a lickspittle . . . not a man to have straightforward love for a woman" (6o)-the kind of inversion he will later trample. "And the fingers of William's left hand closed firmly, surreptitiously, as the hero approached." Giles's homophobia detects William as one who commits the crime that has no name: Giles "knew not his name; but what his left hand was doing. It was a bit of luck-that he could despise him, not himself" (110-11). The homosocial network of animosity is much like that between Grandcourt and Lush as well as Daniel, but Woolf treats sexual practice more suggestively than Eliot would have dared to do. In context, however, only Giles and the alert reader notice that William is masturbating. 
Even Isa, who now dissents from the worship of Giles, was once susceptible to phallus worship. As in Daniel Deronda, courtship figures in this novel as a predatory sport, but the myth of Isis seems to determine that the sport be fishing. The young Olivers "had met first in Scotland, fishing. . . . Her line had got tangled; she had given over, and had watched him with the stream rushing between his legs, casting, casting - until like a thick ingot of silver bent in the middle, the salmon had leapt, had been caught, and she had loved him" (48). Although Giles is fisherman, not fish, in this memory, he seems to be Osiris (pictured carrying a stick) retrieving his own phallus from the water; the syntax suggests it may be the salmon whom Isa loves. A memory of fishing also binds the sister and brother household gods, Lucy and Bart; we recall their Wordsworthian childhood like the Tullivers', "when she had trotted after him as he fished." Though Lucy and Isa are femininely "shocked" by the "blood" of this sport (21), Isa like Gwendolen has predatory impulses equivalent to a man's. Isa cannibalistically serves fish for lunch; Giles, coming home to dine, feels "held . . . fast, like a fish in water" by his work in the City (47), but hurriedly eats his fillet of sole (soul?).

Though Giles can be victim, he remains the most empowered object of patriarchal desire; at Pointz Hall, only Isa and Lucy resist this sexual, economic, and political aggressor. His father loves and searches for him, for the good reason that they are aspects of the same principle. Whether as Christian saints or as phases of Osiris, they are credited with a kind of missionary imperialism. As king of Egypt, Osiris instilled morals, instituted laws, and improved the agriculture of his people before spreading enlightened religion through Arabia, Asia, and Europe (Lemprière 754). Saint Bartholomew is credited with spreading the gospel in India and elsewhere; Bart, retired from the Indian Civil Service, dreams of cowing savages in the parched desert (17).$^{39}$ Bart is always accompanied by his Afghan hound, Sohrab, like the wild beast often carved at the feet of a saint to signify that "he cleared wasteland, cut down forests, and substituted Christian culture and civilisation for paganism and the lawless hunter's life" (Jameson 1: 28$).^{40}$

In every respect, the son seems less the accomplished ruler and

\footnotetext{
${ }^{39}$ Bartholomew is the apostle "in whom there is no guile," according to the Gospel of John (Attwater; Jameson 1: 244-45). Like his sister Lucy's patron saint, Bart's is associated with the instrument of his martyrdom, the knife.

${ }^{40}$ The hound's name alludes to Arnold's "Sohrab and Rustum," the blank-verse tale of a battle that ends in peace when the long-lost father, Rustum, unknowingly kills his disguised son, Sohrab-a strange reversal of the Oedipal conflict fittingly associated with the Victorian Bart.
} 
more the combative quester. The dream of empire has become a nightmare, and Giles can only dress as a cricketer and fulminate against the coming assault from Europe (46). Like Grandcourt stifling his wife-colony and his sidekick Lush, Giles intimidates his wife and the "halfbreed" Dodge as though they are less civilized than he. Yet the stockbroker resents the system by which he himself has been civilized, forced to spend his life, according to Lucy, "buying and selling-ploughs? glass beads was it? or stocks and shares? - to savages who wished most oddly-for were they not beautiful naked?to dress and live like the English?" (47). The legend of Saint Giles is that of the nature-loving outsider rather than the colonizer: Giles was a hermit whose pet hind was slain by an arrow of the king's hunting party (his emblem is the arrow). As saint he became the patron of cripples and the indigent, but Woolf's Giles would discipline any deviation from an upright norm. (As though to anticipate Foucault, "Cripplegate, St. Giles's, Whitechapel" are invoked by the Victorian policeman in the pageant; they are more madhouses or prisons than churches, in which workers must labor to pay "the price of Empire" [163].)

The young English gentleman is further characterized by more primitive narratives of the elements; loosely, he is the earth to Isa's water, Bart's sun or fire (17), and Lucy's air. If Grandcourt has turned to slime, Giles is the hard dry earth of action that Isa must water. ${ }^{41}$ Giles gravitates away from his ethereal aunt, who has "nothing in her to weight a man like Giles to the earth," toward the magnetic Mrs. Manresa: he "would keep his orbit so long as she weighted him to the earth" (116-19). Both father and son feel renewed by Mrs. Manresa, the phallic goddess associated with mud, or earth made fertile by water.

Besides the inferred sex act with Mrs. Manresa in the greenhouse, Giles commits only one overt "act" before the end: an instinctive assault on the feminine, the homosexual, and the cycle of birth and death that encompasses him. It is also a declaration of war that commemorates Saint George's victory over the dragon as well as countless similar legends founded on the ancient conflict between the patriarchal thunder god and the serpent of the goddess (Stone 67-68, 204-10; Frye 187-91):

\footnotetext{
${ }^{41}$ Bart consults "Lemprière" on the origin of the superstition "Touch wood; touch earth; Antaeus" (25), unconsciously alluding to his son; Hercules stifles Antaeus in the air because, like Giles, Antaeus draws "new strength" from the earth (Lemprière 677). Miss La Trobe and those who gaze into the lily pond find new life in the mud, but Giles resists such contemplation.
} 
This dry summer the path was strewn with stones. He kicked-a flinty yellow stone . . . as if cut by a savage for an arrow. A barbaric stone; a pre-historic. Stone-kicking was a child's game. He remembered the rules. ... The gate was a goal; to be reached in ten. The first kick was Manresa (lust). The second, Dodge (perversion). The third, himself (coward). . . . He reached it in ten. There, couched in the grass, curled in an olive green ring, was a snake. Dead? No, choked with a toad in its mouth. . . It was birth the wrong way round-a monstrous inversion. So, raising his foot, he stamped on them. . . . Action relieved him. (98-99)

The arrow of Saint Giles becomes part of a child's game expressing unconscious prehistory; what once were sins ("lust") are now called drives. Combat once thought heroic now seems merely the lesser of two evils, like putting an animal out of its misery, and it brings him no glory ("Silly little boy, with blood on his boots," Isa later silently taunts him [111]). Giles is a less hypocritical tyrant than Grandcourt, at least, in that he does his kicking himself; he may "pose [as] one who bears the burden of the world's woe, making money for [Isa] to spend" (111), and he may impose the double standard, but he acts on his appetites as crudely as a child. Isa in contrast must act in the other sense; like Gwendolen she must perform a marital "cliché conveniently provided by fiction" (14), that of the loving, obedient wife.

Yet in spite of old gender conventions, the goddesses in Between the Acts have far more say in the course of events than the two female "Fates" in Daniel Deronda. Isa, Lucy, Miss La Trobe, even Mrs. Manresa participate in an often exuberant colloquy of folklore without always having to compete, like females in a romantic comedy, for the scarce commodity of male sanction. Much of the ancient consciousness of womanhood that they share seems to center on the lily pond, a vessel of perpetual emotions complementing the alabaster vase at the core of the house. "It was in that deep centre, in that black heart, that the lady had drowned herself. Ten years since the pool had been dredged and a thigh bone recovered. Alas, it was a sheep's, not a lady's. . . . But, the servants insisted, they must have a ghost; the ghost must be a lady's; who had drowned herself for love"(44). The common version of the past holds more lasting power than historical fact, though it tells a tale of feminine undoing. Mrs. Manresa openly sides with such power as no lady in an Eliot novel may. If servants "must have their drowned lady," "so must I!" she cries, in a sense refusing to grow up and become civilized. Her association with the freedom of the unconscious is explicit: "A spring of feeling bubbled up through her 
mud. They had laid theirs with blocks of marble" (44-45). This barbaric power also entails the kind of prophecy of the warring man's death that is attributed to Gwendolen. Mrs. Manresa claims she "knew . . . that Ralph, when he was at the war, couldn't have been killed without her seeing him - 'wherever I was, whatever I was doing,' she added, waving her hands so that the diamonds flashed in the sun" (44). These diamonds, not unlike Mrs. Grandcourt's jewelry, have a guilty history (they were "dug out of the earth with his own hands by a 'husband' who was not Ralph Manresa"), but the modern woman can ignore past scandal and enjoy herself (39-40).

In contrast with Mrs. Manresa, Isa more closely resembles the martyred Lady Ermyntrude than the servants, though she serves the common life. She murmurs, "How am I burdened with what they drew from the earth; memories; possessions. . . 'Kneel down,' said the past. 'Fill your pannier from our tree. Rise up, donkey. Go your way till your heels blister. . . ' That was the burden . . . laid on me in the cradle; murmured by the waves; . . . crooned by singing women; what we must remember; what we would forget" (155). Isa figures as history's obedient beast of burden, but she also has the privilege of preserving the song (burden) of buried collective memory. The nursery tales of crooning women have a subliminal power, though they record oppression. ${ }^{42}$ The king is in his counting house; rich man, poor man, beggar man, thief-such is the hierarchy. Although Eliot and Woolf suggest that a trance may keep the "queen" in her parlor, eating bread and honey as war breaks out outside, they do not imply that she is powerless in her separate sphere. She can summon a vast history in which war is just a recurring fit, part of a cycle of love, hate, peace.

If love and war are just the same old story over and over, art promises to retrieve some sense from the senseless repetition. Indeed art has become the inviting vocation for women in both novels as though to channel the rhythmic waves. Miss La Trobe's pageant becomes, in the present day, an Isiac ritual, the jerking mirrors shattering the mimetic order of difference (Haller, "Isis,".116-17), insisting through nonsensical repetition, "O we're all the same"-alike brutal and vile. Yet with a few affirmative qualifications, the ensuing music gathers "the whole population of the mind's immeasurable profundity" to unite "us," drawing "from chaos and cacophony measure" (187-89). Such would be the ambition of the pageant itself and the

\footnotetext{
${ }^{42}$ Arthurian romance and fairy tales lurk in each novel like popular memories. Were we each chosen or cursed in the cradle; are we each, like Guinevere or Sleeping Beauty, a pawn of national or sexual destiny?
} 
novel as a whole: through art to unite the community in spite of its monstrous nature, moving beyond the masquerade of gender.

Thus the drawing room in the evening dissolves to expose natural appetites: "There in that hollow of the sun-baked field were congregated the grasshopper, the ant, and the beetle. . . Bartholomew, Giles and Lucy polished and nibbled and broke off crumbs" (216). This is no domesticated green world for an As You Like It, but a zone of terror such as Gwendolen encounters behind the Whispering Stones. At the last, Isa and Giles face each other in silence:

Before they slept, they must fight; after they had fought, they would embrace. From that embrace another life might be born. But first they must fight, as the dog fox fights with the vixen, in the heart of darkness, in the fields of night.

The great hooded chairs had become enormous. . . . The house had lost its shelter. It was night before roads were made, or houses. It was the night that dwellers in caves had watched from some high place among rocks.

Then the curtain rose. They spoke. (219)

This timeless sexual battle dissolves the individual in the species as it levels male and female; before property and boundary, the fight seems more equal. This scene, further, has been set by a collaboration of crooning women. Miss La Trobe is answering Isa's earlier unspoken wish: "Surely it was time someone invented a new plot, or that the author came out of the bushes . . ." (Woolf's ellipses; 215). But Isa's wish itself was an answer to Miss La Trobe's even earlier vision as she drank in the smoky pub in a ritual reminiscent of Isis: "Words rose above the intolerably laden dumb oxen plodding through the mud. Words without meaning-wonderful words. . . There was the high ground at midnight; there the rock; and two scarcely perceptible figures. Suddenly the tree was pelted with starlings. She set down her glass. She heard the first words" (212). War and literary history fade as we enter the world of the collective unconscious. Cruelty and exploitation would not vanish in a return of the beasts (like a return of the Jews); the allusion to Conrad's heart of darkness should chasten our millenarian hopes. Yet just as language might begin to lose its patriarchal loyalties in a return to semiotic origins, Miss La Trobe might flourish, though she is nobody famous, as the medium for a new life, a kind of natural art, fertilized by mud and birds and oxen, by the almost indistinguishable dog fox and vixen. 


\section{Artistic Vocation and the Great Women of Letters}

The archaeological quest, started so long ago, does not return quite to its beginning; at least we have retrieved some sense of the demonic power of feminine ancient consciousness. But the quest was launched by the question of vocation, and should return to that point, as vocational difficulties still remain. These novels have not shown us the way to reconcile women's ambitions and history as men have made it. Why, to put a recurring feminist question most plainly, why are there no flourishing women artists in the works of either author? As Woolf observed, Eliot's heroines present "the incomplete version of the story of George Eliot herself" ("GE" [1919] 160). A degree of incompleteness affects Woolf's heroines as well, though one may cite the achievements of Lily Briscoe, Orlando, and Miss La Trobe. If the woman artist in these authors' oeuvres betrays some lack when compared to the grand old woman of English letters, why-and here is the second question to be entertained in this section-why do Eliot's and Woolf's most archaeological novels seem so crowded with women artists? (I will return later to the question of why criticism focuses so much on women authors' female characters.)

As we have seen, Eliot's novels never resolve the clash of women's ambition and erotic plots, and at last in Daniel Deronda the tendency to divide (while interweaving) the gendered public and private narratives, which first became marked in Felix Holt, has reached such extremes that many have been tempted to sever the hostile parts from each other. ${ }^{43}$ Though incapable of forming a stable, "organic" whole (Shuttleworth 201), the Gwendolen and Daniel stories reveal a fundamental interdependence in the need of the latter to silence the former. Though Woolf has broken the silencing effect of the romantic plot, and though she creates independent artists such as Orlando and Lily Briscoe, she as much as Eliot confirms Carolyn Heilbrun's observation that "women writers do not imagine women characters with even the autonomy they themselves have achieved" (Reinventing 71). Women of vocation in Woolf's fiction must espouse some measure of obscurity, in keeping with the lingering ideology of influence.

In the final novels, however, both Eliot and Woolf seem to question more than ever the enforced noble failure of creative female characters.

\footnotetext{
${ }^{43}$ Henry James, in "Daniel Deronda: A Conversation" (1876), was one of the first to advocate the division of a novel excellent in parts; see Fleishman, "Charisi," 86-87; Lerner and Holmstrom 138-43, 153-55.
} 


\section{Greatness Engendered}

Daniel Deronda and Between the Acts repeat the female artist figure as they repeat images of goddesses, and they center women's artistic endeavor in the communal ritual of theater. As performers, the women enact their resistance to the law of fathers and husbands, but they tend to conceive of their art as depending on male judgment, and ultimately they give it up. Only Miss La Trobe, purged of self-regard and feminine modesty, defies her audience and launches her own creation yet again. Her remarkable temerity-she may become greatis the exception to the rule of these novels, and a heavy price is paid for it in the prior history of women's silent submission. The Alcharisi has been great, but has given it up-and unlike Dorothea, she does not like giving up. I wish to survey briefly the vocational options for women in the last novels before attending most closely to the two figures who are publicly recognized as artists in their own right-the Alcharisi and Miss La Trobe (whose names, not incidentally, imply the recurring patterns or tropes of history). ${ }^{44}$

In these final novels the authors subvert the commandment of domestic sacrifice by the portrayal of so many cygnets in the brown pond, and no suitable outlets in family life. The usual alternatives for women, marriage and motherhood, are given little genuine appeal; the widow Mrs. Davilow tells her daughter, "Marriage is the only happy state for a woman," miserable as her own marriages have been (DD 58). Certainly, the young heroines discover no happiness in that state, but only a bitter contest of wills. Motherhood has been presented throughout Eliot's and Woolf's novels more as a woman's estrangement from herself than as her proper vocation (Zimmerman, " 'Mother's History,' " 82-84; N. Auerbach, Imprisonment, 171-83); it generally happens after the heroine's story is over, as in the Finale of Middlemarch. Between the Acts, for the first time in either Eliot's or Woolf's novels, represents a young heroine, Isa, as a mother. It is easier for dead mothers, like those of Mirah and Mordecai and of Lucy and Bart, to become "objects of universal veneration" like Mrs. Ramsay (81). Living mothers are almost always presented as more flawed, either overindulgent (like Mrs. Davilow) or unloving (like the Alcharisi, who openly resents motherhood as a poor substitute for her career). The egotists Gwendolen and Mrs. Manresa and the artist Miss La Trobe (like Lily Briscoe) logically remain childless, whereas Mrs.

\footnotetext{
${ }^{44}$ I call her "the Alcharisi" as many critics have done, though doubling the definite article, because it suits English usage. "Charisi" refers to return from exile. Haller ("Isis" 124-25) and Maika (11-12) offer plausible derivations for La Trobe's name, but it is also an allusion to the tropism that guides the germinating seed: a direction of life. And I think her honorific, "Miss," becomes a pun.
} 
Swithin, long ago a wife and mother of two, has left such definitive roles behind; she might be a celibate priestess (rather like an aged Mrs. Dalloway). Gwendolen and Isa, caught within the heterosexual hothouse, still wish to preserve a self from maternity: Gwendolen dreads having a child, and Isa escapes the nursery in her imagination.

If marriage appears to be the exchange of women, if romantic love entails a rivalry between women, if motherhood devours the woman's identity, what has become of the English lady's "mission" to spread the influence of fellow-feeling? The demand "what can I do?" has become a clamorous mob of desires and impulses. Though Gwendolen and Isa must carry the burden of ancient consciousness and lose themselves in worldwide feelings, their thought-arrows will hit their mark. Simply by reenacting a counter-history of emotions always in being, women may undermine the public history of wars and conquests, acting as a kind of feminine universality dissolving the claims of a universalizing civilization. If this myth is not always so far-reaching in Eliot's and Woolf's novels, often "the ancient consciousness of woman, charged with suffering and sensibility, ... seems in [their heroines] to have . . . overflowed and uttered a demand for something" ("GE" [1919] 159) through artistic expression, curtailed as that expression is shown to be.

For several of the female characters in Daniel Deronda and Between the Acts, performing is a livelihood (for which they are paid directly or indirectly). ${ }^{45}$ Theater seems to focus the genteel woman's captivity-she must act her part-as well as her secret freedom to act any part, while it stresses communal ritual, as we have seen. Historically, theater had been one of the few dignified (if not wholly respectable) vocations open to women; the alternatives of teaching or the Meyricks' ladylike handiwork would humiliate Gwendolen. It is never suggested that Gwendolen might write for a living. Eliot allows no lady novelists in her fiction until the last novel, and then only the wealthy, "ridiculous" Mrs. Arrowpoint whose "literary tendencies" certainly yield silly results (Gwendolen makes fun of her: "Home-made books must be so nice" [74-75]). The lady novelist could retain her respectability as a lady but hardly win honor as a novelist, at least not in an ambitious novel by a Victorian woman, since the risk of autobiography would be too great.

Eliot allots professional artistic talent only to Jews, Klesmer and Daniel's mother and wife-to-be. The latter women artists emphatically

\footnotetext{
${ }^{45}$ Nina Auerbach depicts "George Eliot as an actress for whom the role of Great Author is merely the culmination of a life of continual self-creation," and she notes the insistent theatricality of the characters in Daniel Deronda (Imprisonment 255-56).
} 
are not English ladies, hence their freedom in public; yet they are allowed only the precarious fame of performers, not originating power. In an essay written when she was about to make her first bid for recognition as a great author, Eliot had warned that lasting fame and greatness, or "the sympathy of mankind with individual genius," is awarded only to "the great poet or the great composer," not the performer. ${ }^{46}$ Moreover, for women the theatrical profession was generally open more to beauty than talent, and thus it could figure as another market for the physical charms that are notoriously shortlived; this fact is part of the warning and protest in the story of the Alcharisi. The actress may seem to rule supreme, but she generally cannot control the form of her career, which vanishes like the bride's power after marriage. The woman novelist, however homely to begin with, may appear to be judged on the substance of her work, not her womanhood; but the woman of letters, too, seems forced into embodiment by a critical public, as we have seen.

The difficulty of reconciling the woman and the artist in the theater of European society is a repeating theme in Eliot's novel. Mirah, though she is a gifted professional singer and actress, abhors public life and is only too grateful to vanish in Daniel's monumental shadow. Gwendolen is Mirah's opposite, an amateur "stunner" of great ambition; she hopes to go on the stage, but learns that her person will only sell on the marriage market. With options closed, the most frankly egotistical of Eliot's young heroines is thus blocked in both ambition and romance plots. The only ambitious professional woman artist in Eliot's fiction is the Alcharisi (Heller 38), the famous diva who combines Mirah's gifts and Gwendolen's will to power. As though to punish her egotism, Eliot has the Alcharisi's public career founder (as Eliot's certainly did not) when, thinking she is losing her talent, she flees into the refuge of marriage and motherhood. ${ }^{47}$ She must assume the roles of daughter, wife, and mother that she had sought to obliterate in her invented persona. Thus for Daniel's wife, lover, and mother, private life triumphs over the artistic career, but not without unresolved tensions.

In Between the Acts, Woolf creates a similar array of frustrated female

${ }^{46}$ See Gallagher, "The Prostitute," 55. Eliot expresses warm admiration for "musical and dramatic artists," but they cannot live into the "next age"; "the memory of the prima donna scarcely survives the flowers that are flung at her feet on her farewell night" ("Liszt, Wagner, and Weimar" 98-99)-the actress as Persephone?

${ }^{47}$ Eliot did fear a loss of command over her public after Middlemarch, as I have noted, and she did, after Daniel Deronda, belatedly marry. The anxiety of the woman artist to continue to meet her own standard of greatness is figured also in Armgart, the opera singer in the poem of that name (1870). 
talent, this time consisting not only of the powers of performance but also the powers of literary creation; in each instance, the woman succeeds in securing a certain independence from male judgment or domination, and there are signs of alliance between women-a kind of alliance conspicuously absent in Eliot's last novel. Lucy stage-manages the rites at Pointz Hall and shares "a common effort to bring a common meaning to birth" with Miss La Trobe, whom she thanks for rousing her "unacted part," Cleopatra (152-53). Mrs. Manresa, a kind of amateur diva, plays Giles Oliver's fantasy of the earth mother without ever yielding to the role of wife, mother, or mistress. Like the Alcharisi, the Manresa gains notoriety and freedom because she is somehow beyond the pale (born in Tasmania, married to a Jew)-like Eliot, both divas are great favorites with the gentlemen but not quite suitable company for the ladies. Mrs. Manresa resembles Leonora Charisi in being massive and queenly, a performer at heart ("she acted her own emotions"), with the power to sway men (DD 691); their presumed licentiousness is part of their fascination. Yet Woolf's portrait of the man's woman is if anything more damning than Eliot's; whereas Leonora insists that "nature gave [her] a charter" - "the voice and the genius matched the face" (728)-Mrs. Manresa has no pretensions to beauty, spouts the clichés of a hedonistic "barbarian" (176), and knows no feminist theory.

It may have become easier in Woolf's fiction for women to escape the hothouse as the Alcharisi strove to do, but somehow the more accessible "strange bright fruits of art and knowledge" ("GE" [1919] 160) lose the flavor of desire; as Isa ignores old books, Mrs. Manresa flaunts her ignorance. Woolf's novel appears to favor the less selfadvertising, less happy Isa over Mrs. Manresa (like Mirah, Isa is a kind of small-voiced singer liable to drown herself); Mrs. Oliver performs the parts of "Sir Richard's daughter" (16), a mother, jealous wife, and potential adulteress, while her most independent act is that of a poet. In contrast with Gwendolen, Isa has a genuine if minor talent that she keeps entirely hidden, though she collaborates with the authors of pageant and novel (Mrs. Manresa even accuses "Mrs. Giles" of having written the pageant [61]).

Finally, Miss La Trobe not only combines the talent and the dedication of the spinster Lily Briscoe, but is also a writer who reshapes the English tradition more radically than Orlando does. Although behind the scenes and excluded from the inner circle of Pointz Hall, the playwright is the most nearly omnipresent character in the book and governs the actions of most of the players; her artistry is both the core of the book, the pageant, and its frame, the new play at the end. Like 
"the Alcharisi," La Trobe's foreign name with its definite article seems to announce her essential difference from the common woman: "Nature had somehow set her apart from her kind" (BA 211). Yet Miss La Trobe has none of the Alcharisi's magical fame and success. She struggles with her unruly audience and material, and is popularly laughed at as "Bossy"; she herself despises the notion of unique authorship or the honors paid to genius (she hides in the bushes, though sometimes behaving like a dictator). Without acclaim, she is nevertheless more artist than woman. Unlike the grand "Princess," Miss La Trobe lacks all the traditional signs of feminine excellence: she is "swarthy, sturdy and thick set," neither "altogether a lady" nor "pure English" (BA 57-58; she bears some resemblance to the "squat," "harsh" lady writer, Mrs. Arrowpoint, or her antecedents, the bluestocking and the strong-minded woman [DD 74]). This lack of charm may be the secret of her continuing artistic license. Daniel's mother, in contrast, is brought briefly before the reader's eyes as she is forced to pay for her charm as well as license; it is like watching a genie forced back into its bottle, a mortal woman's body. Her career is long since dead and her body is dying as the facts of her family bondage enforce their consequences. Was she too much "woman" to be an enduring artist, or must she fail because "the woman [was] lacking in her" (723)?

Miss La Trobe avoids the capitulation to heterosexual "womanhood" of each of the other talented women in the final novels. Though Woolf seems to endorse the playwright's vocation, she holds some gifts in reserve. Miss La Trobe's art is a refreshing departure from high modernism and an ambitious redaction of drama through the millennia. But the novel does not risk taking the pageant too seriously; it is on the surface an abortive, provincial performance by an unknown, not received as the work of a grand old woman of English letters. The playwright moreover lacks her creator's charm, social standing, and lifelong helpmeet: she lives in lonely poverty, deserted by her actress-lover. These gifts may be withheld to avoid autobiography, to avoid implausible wish-fulfillment, or-and this is the most telling motive-to retain the obscurity of "one who seethes wandering bodies . . . in a cauldron" (153). The witch-artist, "Anon.," thus exemplifies feminine heroism and defies old notions of greatness.

With varying degrees of talent and ambition, then, the primary female characters in these final novels yearn to triumph in art but either give it up or fail in life, or both. Eliot and Woolf themselves escaped the same old story of the talented woman's tragedy by retelling that story-their own artistic success bought at the price of their heroines' apparent failure or covert greatness. Their full-fledged au- 
thorship defied the boundaries of woman's sphere, even as their texts to some degree retained an ideal of feminine self-effacement. At the same time, there is a subtle triumph over the exclusive aesthetic standards that denigrate women's art. Though, for example, Gwendolen is an amateur, no one has ever performed more powerfully under more duress the part of charming English lady. Similarly, an ephemeral village pageant, a labor of the folk, becomes a contender for the worthiest prize of modernism: being so old, indigenous, and authentic that it is truly new.

The extent of Miss La Trobe's command of a collective heritage bears further remark, as only Orlando among these authors' artist figures can match it (the Alcharisi must be silenced in order to contribute to her racial destiny). Miss La Trobe seems to take charge of a female literary tradition when she produces the Victorian scene in the pageant, signaling the women novelists' need to escape the marriage plot and the heroine's fate. Here Miss La Trobe displays the kind of metacritical command that Eliot and Woolf sought in their essays, and she braves the juxtaposition of "reality" and artifice as no novelist may (can "real swallows" cross a page as they do the "painted" set?[BA 164]). The Victorian scene in the pageant is a pastiche of the canonical Victorian novel that might be called wooing in the missionary position. In a bourgeois picnic party distilling scenes from a range of novels, from Emma and Jane Eyre to The Voyage Out and A Passage to India, Edgar Thorold, another St. John Rivers, woos Eleanor Hardcastle to choose "a lifetime in the African desert among the heathens" (166). Mrs. Hardcastle and the chorus mimic Mrs. Bennet in Pride and Prejudice (as well as the effusive ramblings of Miss Bates in Emma): "O has Mr. Sibthorp a wife?" (168-69). Novels had to ask other questions than who would marry the eligible newcomer, the Darcy or Grandcourt, as Eliot and Woolf show. Further, La Trobe's pageant, like Eliot's and Woolf's novels, reveals the political and cultural exploitation behind the seemingly innocent pleasures of fiction: as love sweetens the submission of the wife, religion gilds the domination of the empire.

Although Miss La Trobe commands much of the grand authorial powers and the Alcharisi has been an eminent artist, it is clear that they suffer deeply, that their lives are loveless, their glory fleeting. Genius is conventionally tormented, of course, as though a happy artist were an oxymoron; a maternal, domestic artist is conventionally an even more monstrous contradiction in terms. But though these female artist figures suffer conventional constraints, they participate indirectly in the genuine sufferings of their creators.

And now I come to a question that may concern readers of the 
preceding comparison of artist heroines and their authors. Why do we ask women writers to represent themselves in fiction? Are women writers less capable than men of distancing themselves from their creations? We must challenge the automatic comparison of female author and heroine (just as we should examine the habit of biographical criticism in which text and female author are especially liable to be confused). Because women's writings are so generally read for access to much-touted feminine privacy, I believe Eliot and Woolf sensed danger in textual self-revelation. Perhaps to complete the artist heroine's story would have seemed to reduce the actual authors' artistic freedom, binding them too closely to the plausibly limited destinies of their female characters and exposing the feminist argument so elegantly presented in more archaeological than vocational terms. Grand old women of English letters should have had the right to disguise in fiction their own ambition plots, as much as they had the right to adopt the point of view of male characters and masculine or androgynous narrators. ${ }^{48}$ But at the same time that they asserted their own claim to the public life of ambition and history, they afforded readers access to an anterior feminine privacy not simply shaped by the individual's heterosexual desire, but by ancient, collective "pulses" of revenge, remorse, fear, and hatred, as well as sexual passion.

Some readers will wonder why I emphasize the incompleteness of Lily, Orlando, Miss La Trobe-don't they flourish in an "other" way? Yes indeed: in the later age, Woolf imagines not only a wider scope for female talent, but also a different model of success without need of patriarchal laurels. As Susan Gubar observes, Woolf and other modernist-feminists placed fewer handicaps on their female artist characters, in part owing to a new valuation of domestic arts (consider Mrs. Ramsay's boeuf en daube) and a new articulation of a silenced "woman's language." Yet these women writers still held their female characters at a remove from their own careers, because, Gubar argues, their own self-assertion had been an inadmissible rejection of their mothers and the "natural and distinct sphere" of womanhood that the feminist-modernists continued to believe in ("Birth of the Artist" 39, 49-50). I would add that Woolf came closer to creating an autobiographical portrait of the artist not only because of a new outlook on female creativity, but also because of the modern fashion for selfreferential art. Moreover, Woolf was able to draw on a tradition that

\footnotetext{
${ }^{48}$ Carolyn Heilbrun restates the difficulty of escaping the feminine plot of subordination to some "other" and of fulfilling a powerful ambition plot: in female biographies, "the public and private lives cannot be linked, as in male narratives" (Woman's Life 2425).
} 
was only beginning in Eliot's day, that of fictional autobiographies of the woman writer, from Aurora Leigh to Dorothy Richardson's Pilgrimage. Yet Woolf's portraits of the woman artist, like Eliot's, carefully distance and contain feminist protest, and perhaps as a result have found a steadier canonical perch than more transparent and permissive autobiographical writings.

While Eliot and Woolf protect their own "impersonal" standing, they also muster greater force in their works by engaging the services of suffering women. Their heroines' fulfillment in both art and life would lessen the archaeological force of their works. What would be the call for unburying the ancient consciousness of woman if the diverse vitality of women today were free to find expression in both vocation and love? And such freedom might only be won-it has yet to be realized for more than a few rare women-by a costly release of repressed, primitive feeling, the human store believed to be guarded by women through the ages. According to the writings of Eliot and Woolf, at least, certain ladies, selfless ones among many, may achieve a greatness engendered by their failed resistance to silence and obscurity.

The Alcharisi and Miss La Trobe, however, are not great martyrs in this sense. Terrifying in their refusal to become "many," part of the herd, in different ways they personify both feminine heroism and the heroism of "man's force." The Alcharisi's life is an operatic performance, the tragedy of the heroic woman that demands a dying aria. Miss La Trobe has harnessed the folk opera of crooning women, and can make a Lady Ermyntrude out of a sheep's thighbone (or Queen Elizabeth's silver cape out of "swabs used to scour saucepans" [83]). Women do not have to replay the dying parts forever; their labors can transform everyday detail into art. At the same time these artists violate the gender code with the rage and hubris of warriors (Miss La Trobe is "an Admiral on his quarter-deck" [62], and the Alcharisi declares, like a Cleopatra, "Men have been subject to me" [730]). This will to dominate reduces, perhaps unfairly, most readers' sympathy for these manly leaders and assures their distance from the implied authors, figures of the most profound consideration of others.

Still, some likeness with the living women authors remains. The Alcharisi seems to confess to Eliot's own defiance of her father's religion and of patriarchal law in her union with Lewes, and perhaps more importantly to her ambition and love of success. Yet the great opera singer, a beautiful Jewess with "masculine" ruthlessness, is not to be mistaken for George Eliot. Miss La Trobe bespeaks Woolf's 
dedicated struggle with her medium and her audience, her sense of isolation as well as her lesbianism. But no one surely would mistake the plain village bohemian for the beautiful lady of Bloomsbury, still less for a "great" woman of letters in traditional terms. It is tempting, however, to imagine Miss La Trobe as in some sense Woolf's reincarnation of Eliot. In her published writings on Eliot, Woolf dwelt on her manliness and ugliness, her lower-class background, her scandalous private life and her seclusion. Naturally, this incarnation is the incomplete story of the Grand Old Woman of Letters. All women artists in these oeuvres are doomed to a degree of failure, however magnificent has been their demand for "art and knowledge" beyond a captive woman's reach. Woolf more than Eliot could dispute the interdependence of artistry, authority, and masculine identity. The later woman author could reach, but she would not unquestioningly grasp. Yet as Woolf uttered her demand for something incompatible with the "facts" of European civilization, in a sense she strove to complete, as her heroines were unable to do, the story of George Eliot herself. 